\title{
BMJ
}

\section{Quality of care in for-profit and not-for-profit nursing homes: systematic review and meta-analysis}

\author{
Vikram R Comondore, resident, ${ }^{1}$ P J Devereaux, associate professor, ${ }^{2}$ Qi Zhou, statistician, ${ }^{2}$ Samuel B Stone, \\ resident, ${ }^{3}$ Jason W Busse, research associate, ${ }^{2}$ scientist, ${ }^{4}$ Nikila C Ravindran, resident, ${ }^{5}$ Karen E Burns, staff \\ physician, ${ }^{6,7}$ Ted Haines, associate professor, ${ }^{2}$ Bernadette Stringer, assistant professor, ${ }^{2}$ Deborah J Cook, \\ professor, ${ }^{2}$ Stephen D Walter, professor, ${ }^{2}$ Terrence Sullivan, president and CEO, ${ }^{8}$ Otavio Berwanger, \\ professor, ${ }^{9}$ Mohit Bhandari, associate professor, ${ }^{2}$ Sarfaraz Banglawala, resident, ${ }^{3}$ John N Lavis, associate \\ professor, ${ }^{2}$ Brad Petrisor, assistant professor, ${ }^{3}$ Holger Schünemann, professor, ${ }^{2,10}$ Katie Walsh, summer \\ research assistant, ${ }^{2}$ Neera Bhatnagar, reference librarian, ${ }^{11}$ Gordon $\mathrm{H}$ Guyatt, professor ${ }^{2}$
}

${ }^{1}$ Department of Medicine, University of British Columbia, Vancouver, BC, Canada V5Z 1M9

${ }^{2}$ Department of Clinical Epidemiology and Biostatistics, McMaster University, Hamilton, ON, Canada L8N $3 Z 5$

${ }^{3}$ Department of Surgery, McMaster University

${ }^{4}$ The Institute for Work and Health, Toronto, ON, Canada M5G 2E9

${ }^{5}$ Department of Medicine, Division of Gastroenterology, University of Toronto, Toronto, M5T 2S8

${ }^{6}$ St Michael's Hospital, Toronto, M5B 1W8

${ }^{7}$ Keenan Research Centre and Li Ka Shing Knowledge Institute,

Toronto, M5B 1W8

${ }^{8}$ Cancer Care Ontario, Toronto, M5G 2L7

${ }^{9}$ Department of Clinical Epidemiology, Federal University of Rio Grande do Sul, Porto

Alegre-RS, Brazil

${ }^{10}$ Italian National Cancer Institute Regina Elena, Rome, 00144, Italy

${ }^{11}$ Health Sciences Library, McMaster University

Correspondence to:PJDevereaux philipj@mcmaster.ca

Cite this as: $B M J$ 2009;339:b2732 doi:10.1136/bmj.b2732

\section{ABSTRACT}

Objective To compare quality of care in for-profit and notfor-profit nursing homes.

Design Systematic review and meta-analysis of observational studies and randomised controlled trials investigating quality of care in for-profit versus not-forprofit nursing homes.

Results A comprehensive search yielded 8827 citations, of which 956 were judged appropriate for full text review. Study characteristics and results of 82 articles that met inclusion criteria were summarised, and results for the four most frequently reported quality measures were pooled. Included studies reported results dating from 1965 to 2003. In 40 studies, all statistically significant comparisons ( $\mathrm{P}<0.05)$ favoured not-for-profit facilities; in three studies, all statistically significant comparisons favoured for-profit facilities, and the remaining studies had less consistent findings. Meta-analyses suggested that not-for-profit facilities delivered higher quality care than did for-profit facilities for two of the four most frequently reported quality measures: more or higher quality staffing (ratio of effect $1.11,95 \%$ confidence interval 1.07 to $1.14, \mathrm{P}<0.001$ ) and lower pressure ulcer prevalence (odds ratio $0.91,95 \%$ confidence interval 0.83 to $0.98, \mathrm{P}=0.02$ ). Non-significant results favouring not-for-profit homes were found for the two other most frequently used measures: physical restraint use (odds ratio $0.93,0.82$ to $1.05, P=0.25$ ) and fewer deficiencies in governmental regulatory assessments (ratio of effect $0.90,0.78$ to $1.04, \mathrm{P}=0.17$ ).

Conclusions This systematic review and meta-analysis of the evidence suggests that, on average, not-for-profit nursing homes deliver higher quality care than do for-profit nursing homes. Many factors may, however, influence this relation in the case of individual institutions.

\section{INTRODUCTION}

Nursing homes provide long term housing, support, and 24 hour nursing care for people who are unable to function independently. Conservative forecasts from the European Union suggest that the need for nursing home care will double in the next 40 years as the population ages. ${ }^{1}$ Many nursing home residents are bound to the routines, diets, and treatments prescribed by the home where they reside. In addition, many of them are unable to advocate for themselves because of physical, medical, cognitive, or financial limitations.

Concerns about quality of care in nursing homes are widespread among academic investigators, ${ }^{2-5}$ the lay press, ${ }^{6-11}$ and policy makers. ${ }^{112}$ Whether a facility is owned by a for-profit or a not-for-profit organisation may affect structure, process, and outcome determinants of quality of care. In the United States, for example, two thirds of nursing homes are investor owned, for-profit institutions; in the United Kingdom, more than half of healthcare beds belong to independent nursing homes for older people, most of which are operated by for-profit institutions. ${ }^{13}$ The type of ownership of nursing homes in Europe varies; countries with previously dominant public healthcare systems (such as Poland) now seek privatisation. ${ }^{14}$ In Canada, $52 \%$ of nursing homes are in for-profit ownership, and not-for-profit care is evenly split between charitable or privately owned not-for-profit facilities and government or publicly owned not-for-profit facilities. ${ }^{15}$ Both for-profit and not-for-profit nursing homes may have both public and private funding.

Several investigators have assessed the relation between for-profit/not-for-profit status and quality of care. ${ }^{16}$ If quality or appropriateness of care varies significantly by ownership, this should influence government policies related to regulatory assessments and the use of public funds for nursing homes. The objective of this systematic review and meta-analysis was to examine the quality of care in for-profit and not-for-profit (privately and publicly owned) nursing homes to enhance the evidence base for public policy. This work is part of our series of systematic reviews 
Evaluation of quality of studies used in meta-analyses: appropriate and inappropriate adjustments

\section{Appropriate adjustments (0-5)}

One point for each of:

- Having an adjusted analysis

- Adjusting for age

- Adjusting for severity of illness (comorbidities)

- Adjusting for presence or absence or severity of dementia

- Adjusting for payment status of residents (government funded $v$ privately funded) Inappropriate adjustments (yes/no)

Yes for adjusting for potential quality of care measures (that is, elements used to assess quality of care in a different study, such as pressure ulcer, restraint use, urinary catheterisation, staffing, or regulatory agency citations)

comparing health outcomes, quality and appropriateness of care, and payment for care in for-profit and notfor-profit care delivery institutions. ${ }^{17-19}$

\section{METHODS}

\section{Search strategy}

We used a multimodal search strategy focused on 18 bibliographical databases, personal files, consultation with experts, reviews of references of eligible articles, and searches of PubMed (for related articles) and SciSearch (for articles citing key publications).

A medical librarian (NB) used medical subject heading terms and keywords from a preliminary search to develop database search strategies. In each database, the librarian used an iterative process to refine the search strategy through testing several search terms and incorporating new search terms as new relevant citations were identified. The search included the following databases from inception to April 2006: Medline, Embase, HealthSTAR, CINAHL, Cochrane

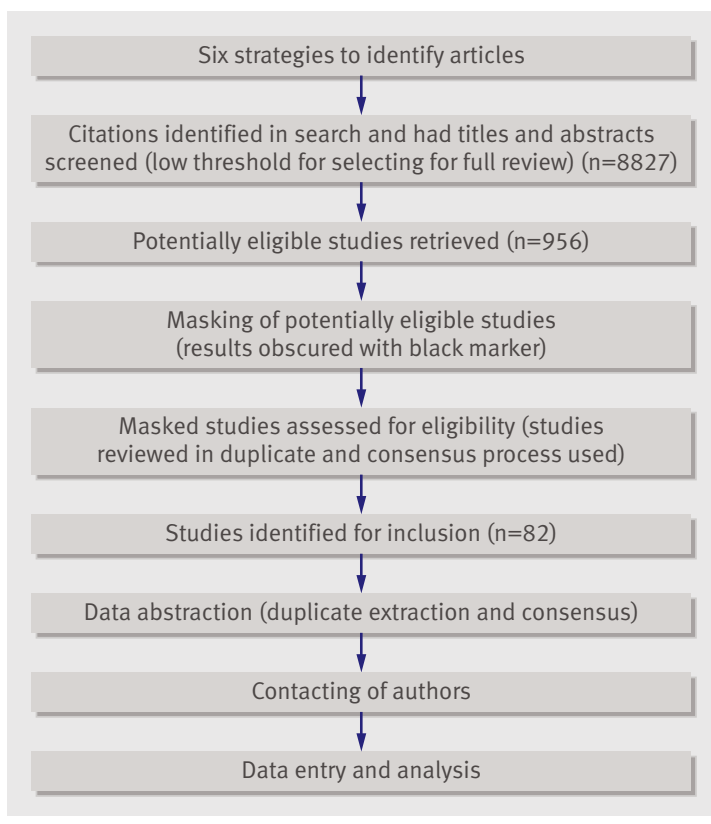

Fig 1 | Flow chart of steps in systematic review
Database of Systematic Reviews, Database of Abstracts of Reviews of Effects, Cochrane Central Database of Controlled Trials, NHS Economic Evaluation Database, AgeLine, Web of Science, Proquest Dissertations and Theses, ABI/INFORM Global, CB CA Reference, EconLit, Proquest European Business, PAIS International, and Worldwide Political Science Abstracts. Search terms included nursing home specific terms (such as nursing homes, homes for the aged, long-term care) combined with ownership terms (such as proprietary, investor, for-profit, and competition). The web appendix gives a complete description of our database search strategies.

\section{Study selection}

Eligibility criteria

Our inclusion criteria were as follows: patients - those residing in nursing homes in any jurisdiction; intervention - for-profit status of the institutions; comparator-not-for-profit status; and outcomes - measures of quality of care in for-profit and not-for-profit nursing homes.

\section{Definition of quality of care}

As described by the American Medical Association, quality of care is "care that consistently contributes to the improvement or maintenance of quality and/or duration of life." ${ }^{20}$ Quality of care was conceptualised by Donebedian as having inter-related structure, process, and outcome components. ${ }^{21}$ Structure pertains to resources used in care (such as staffing). Process refers to action on the patient (such as use of restraint and urethral catheterisation). Outcome indicators assess the patient's end result (such as pressure ulcers). Many quality of care instruments have been proposed, although none has been universally accepted. ${ }^{22}$ Consequently, we used measures that authors defined as representing "quality of care" or "appropriateness of care," provided that they defined a priori what constituted "good" or "poor" quality of care. The most frequently used quality measures were as follows.

Number of staff per resident or level of training of staff The US Medicare/Medicaid nursing home regulations emphasise the importance of this measure of structure. ${ }^{23}$ Studies have consistently shown a positive association between staffing and measures of both process and outcome quality. ${ }^{24-26}$

Physical restraints -Although use of physical restraints can prevent patients from injuring themselves, restraints diminish a patient's self esteem and dignity. By restricting mobility, they lead to both physical deterioration and the formation of painful pressure ulcers. ${ }^{2427}$ An Institute of Medicine report emphasised use of restraints as an important process measure. $^{23}$

Pressure ulcers - The importance of this outcome quality measure was also stressed by the Institute of Medicine. Pressure ulcers are preventable and are associated with pain and infection risk. ${ }^{23}$

Regulatory (government survey) deficiencies-Deficiency citations by a regulatory body cover many aspects of 
Table 1 Number of studies with quality of care comparisons favouring particular ownerships*: overall and staffing results

\begin{tabular}{|c|c|c|c|c|c|c|}
\hline Quality of care measure & Summary of study characteristics & $\begin{array}{l}\text { All statistically } \\
\text { significant } \\
\text { comparisons } \\
\text { favoured NFP }\end{array}$ & $\begin{array}{l}\text { Most statistically } \\
\text { significant } \\
\text { comparisons } \\
\text { favoured NFP }\end{array}$ & $\begin{array}{l}\text { Mixed } \\
\text { results or } \\
\text { direction } \\
\text { unclear }\end{array}$ & $\begin{array}{l}\text { Most statistically } \\
\text { significant } \\
\text { comparisons } \\
\text { favoured FP }\end{array}$ & $\begin{array}{l}\text { All statistically } \\
\text { significant } \\
\text { comparisons } \\
\text { favoured FP }\end{array}$ \\
\hline $\begin{array}{l}\text { Quality overall with any quality of } \\
\text { care measure (FP } v \text { NFP) }\end{array}$ & $\begin{array}{l}82 \text { studies with data from } 1965-2003 \\
\text { ( } 1 \text { from Australia, } 5 \text { from Canada, } 1 \text { from Taiwan, } \\
74 \text { from United States); } 15 \text { collected primary data, } \\
\text { and } 1 \text { supplemented primary data } \\
\text { with government survey data }\end{array}$ & 40 & 2 & 37 & 0 & 3 \\
\hline $\begin{array}{l}\text { Quality overall with any quality of } \\
\text { care measure (FP } v \text { private NFP) }\end{array}$ & $\begin{array}{l}34 \text { studies with data from } 1965-2003 \text { ( } 1 \text { from } \\
\text { Australia, } 1 \text { from Canada, } 38 \text { from United States); } \\
3 \text { collected primary data, and } 1 \text { supplemented } \\
\text { primary data with government survey data }\end{array}$ & 16 & 2 & 16 & 0 & 0 \\
\hline $\begin{array}{l}\text { More, or more extensively } \\
\text { trained, staff }\end{array}$ & $\begin{array}{l}23 \text { comparisons with data from 1965-2003 } \\
\text { ( } 2 \text { from Canada, } 21 \text { from United States) }\end{array}$ & 16 & 0 & 7 & 0 & 0 \\
\hline
\end{tabular}

FP=for-profit; NFP=not-for-profit.

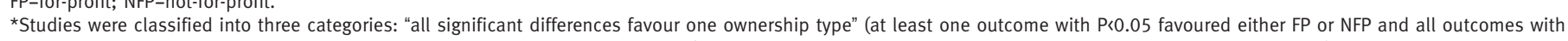

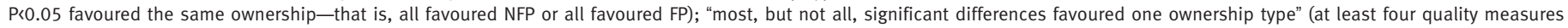
with $\mathrm{P}<0.05$ and three times as many outcomes with P<0.05 favoured one ownership than favoured the other); "mixed results" (all other results).

nursing home care. Their strength lies in providing an overall measure of quality. Considerable work has gone into developing valid overall deficiency measures. ${ }^{4}$

\section{Definition of nursing home}

In keeping with other definitions, ${ }^{28}$ we defined a nursing home as a home for elderly people in which most residents require daily nursing care. We included all long term care facilities that met this definition, including those studies that specifically evaluated "skilled nursing facilities" and special care facilities such as those for patients with Alzheimer's disease.

\section{Assessment of study eligibility}

Teams of two reviewers independently screened the titles and abstracts of all citations identified in our search, and if either reviewer thought that a citation might be eligible we retrieved the study for full text review. Research personnel who were not involved in the screening or data abstraction process masked the study results from the text and tables of potentially eligible articles by using a black marker. Teams of two reviewers independently evaluated each masked article to determine eligibility. All disagreements were resolved by consensus, with discussions with the project lead (VRC) about eligibility criteria as required. In the event of ambiguity about whether the outcome was a measure of quality of care, we erred on the side of being inclusive.

\section{Data extraction and study quality evaluation}

Multiple teams of two reviewers independently abstracted data from included articles. We collected data on geographical area, year, data source, unit of measurement (number of residents or nursing homes), and quality of care measure. We developed and applied a 0-5 scale for evaluating appropriate adjustments and a yes/no scale for inappropriate adjustments (box). We explored whether appropriate and inappropriate

\begin{tabular}{|c|c|c|c|c|c|c|}
\hline Quality of care measure & Summary of study characteristics & $\begin{array}{l}\text { Favoured NFP } \\
\qquad(P<0.05)\end{array}$ & $\begin{array}{l}\text { Non-significantly } \\
\text { favoured NFP }\end{array}$ & $\begin{array}{l}\text { Direction } \\
\text { unclear }\end{array}$ & $\begin{array}{l}\text { Non-significantly } \\
\text { favoured FP }\end{array}$ & $\begin{array}{l}\text { Favoured FP } \\
(P<0.05)\end{array}$ \\
\hline Lower pressure ulcer prevalence & $\begin{array}{l}24 \text { comparisons with data from 1984-2003 } \\
\text { (1 from Canada, } 23 \text { from United States) }\end{array}$ & 7 & 10 & 3 & 3 & 1 \\
\hline Lower physical restraint prevalence & $\begin{array}{l}21 \text { comparisons with data from 1987-2003 } \\
\text { (all from United States) }\end{array}$ & 10 & 4 & 0 & 3 & 4 \\
\hline Fewer deficiencies on government surveys & $\begin{array}{l}19 \text { comparisons with data from 1976-2003 } \\
\text { (all from United States) }\end{array}$ & 10 & 5 & 2 & 2 & 0 \\
\hline Lower urethral catheterisation prevalence & $\begin{array}{l}10 \text { comparisons with data from 1984-2003 } \\
\text { (all from United States) }\end{array}$ & 4 & 2 & 3 & 0 & 1 \\
\hline Lower mortality & $\begin{array}{l}4 \text { comparisons with data from 1984-99 } \\
\text { (1 from Canada, } 3 \text { from United States) }\end{array}$ & 1 & 2 & 1 & 0 & 0 \\
\hline Lower psychoactive drug use prevalence & $\begin{array}{l}4 \text { comparisons with data from 1997-2003 } \\
\text { (all from United States) }\end{array}$ & 3 & 1 & 0 & 0 & 0 \\
\hline More feeding tubes & $\begin{array}{l}3 \text { comparisons with data from 1990-9 } \\
\text { (all from United States) }\end{array}$ & 3 & 0 & 0 & 0 & 0 \\
\hline Lower hospital admission rate & $\begin{array}{l}3 \text { comparisons with data from } 1994-9 \\
\text { (1 from Canada, } 2 \text { from United States) }\end{array}$ & 1 & 1 & 0 & 1 & 0 \\
\hline
\end{tabular}


Table $3 \mid$ Characteristics of studies comparing private for-profit and private not-for-profit nursing home quality of care

\begin{tabular}{|c|c|c|c|}
\hline \multirow[b]{2}{*}{ Study } & \multirow[b]{2}{*}{$\begin{array}{l}\text { Place; year; data source }{ }^{\star} \text {; } \\
\text { No of residents or nursing homes }\end{array}$} & \multicolumn{2}{|c|}{ Factors controlled or adjusted for } \\
\hline & & $\begin{array}{l}\text { Appropriate: age, severity of illness, severity of } \\
\text { dementia, and payment status adjustments }\end{array}$ & $\begin{array}{l}\text { Inappropriate: quality measures used in } \\
\text { other studies; measures of intensity of care }\end{array}$ \\
\hline Levey et al $1973^{\text {w1 }}$ & $\begin{array}{l}\text { Massachusetts; } 1965 \text { and } 1969 \text {; state public health } \\
\text { department; } 129 \text { homes in each year }\end{array}$ & Payment status & None \\
\hline $\begin{array}{l}\text { Cohen and Dubay } \\
1990^{\text {w2 }}\end{array}$ & $\begin{array}{l}\text { United States; 1981; MMACS; } 694 \text { FP } \\
\text { and } 235 \text { private NFP homes }\end{array}$ & $\begin{array}{l}\text { Severity of illness (long term care index of function), } \\
\text { dementia (\% confused or disoriented), payment status (\% } \\
\text { of Medicare patients in facility) }\end{array}$ & None \\
\hline Elwell $1984^{\text {w3 }}$ & $\begin{array}{l}\text { New York state; 1976; Residential Health Care Facilities } \\
\text { Report (NY); } 258 \text { FP and } 130 \text { private NFP homes }\end{array}$ & $\begin{array}{l}\text { Severity of illness (ADLs), dementia (proportion of } \\
\text { residents with totally impaired alertness), payment status } \\
\text { (proportion of days paid for by Medicaid) }\end{array}$ & None \\
\hline Lee $1984^{\text {w4 }}$ & $\begin{array}{l}\text { lowa; } 1980-1 \text {; lowa Department of Health; } \\
254 \text { FP } \\
\text { and } 103 \text { private NFP homes }\end{array}$ & Unadjusted analysis & Unadjusted analysis \\
\hline $\begin{array}{l}\text { Wiesbrod and } \\
\text { Schlesinger } 1986^{\text {w5 }}\end{array}$ & $\begin{array}{l}\text { Wisconsin; } 1976 \text {; State Division of Health; } 220 \text { FP } \\
\text { and } 134 \text { private NFP homes }\end{array}$ & $\begin{array}{l}\text { Adjusted analysis but none of } 4 \text { selected appropriate } \\
\text { factors included }\end{array}$ & None \\
\hline $\begin{array}{l}\text { Lemke and Moos } \\
1989^{\text {w6 }}\end{array}$ & $\begin{array}{l}\text { United States; year not listed; research nurses; } 44 \text { FP } \\
\text { and } 44 \text { private NFP homes }\end{array}$ & Unadjusted analysis & Unadjusted analysis \\
\hline Pearson et al $1992^{w 7}$ & $\begin{array}{l}\text { Australia; } 1988-90 \text {; authors collected data; } 120 \text { FP } \\
\text { and } 80 \text { private NFP homes }\end{array}$ & Severity of illness (\% of high need residents) & Staffing (\% of nurses who were RNs) \\
\hline Graber $1993^{\text {w8 }}$ & $\begin{array}{l}\text { North Carolina; } 1991 \text {; OSCAR; } 167 \text { FP } \\
\text { and } 14 \text { private NFP homes }\end{array}$ & Unadjusted analysis & Unadjusted analysis \\
\hline $\begin{array}{l}\text { Aaronson et al } \\
1994^{\mathrm{w} 9}\end{array}$ & $\begin{array}{l}\text { Pennsylvania; } 1987 \text {; MMACS; } 269 \text { FP } \\
\text { and } 180 \text { private NFP homes }\end{array}$ & $\begin{array}{l}\text { Varied by analysis: staffing_-severity of illness (long term } \\
\text { care index of resident function), payment status; pressure } \\
\text { sores-age (\% aged } \geq 85 \text { ), severity of illness (long term } \\
\text { care index of resident function), payment status; restraint } \\
\text { use-dementia (proportion of confused patients per } 100 \\
\text { beds), payment status (Medicaid use rate) }\end{array}$ & $\begin{array}{l}\text { Varied by analysis: staffing—none; pressure } \\
\text { sores—restraint use; restraint use-RN to } \\
\text { resident ratio }\end{array}$ \\
\hline Moseley $1994^{\mathrm{w} 10}$ & $\begin{array}{l}\text { Virginia; } 1983-5 \text {; state medical assistance services using } \\
\text { long-term care information system; } 174 \text { homes with } 2362 \\
\text { FP and } 787 \text { private NFP residents }\end{array}$ & $\begin{array}{l}\text { Age, severity of illness (ADLs), dementia } \\
\text { (oriented/disoriented) }\end{array}$ & None \\
\hline Sainfort et al $1995^{\mathrm{w} 11}$ & $\begin{array}{l}\text { Wisconsin; 1982; research teams; } 44 \text { FP } \\
\text { and } 46 \text { private NFP homes }\end{array}$ & Unadjusted analysis & Unadjusted analysis \\
\hline Holmes $1996^{\text {w12 }}$ & $\begin{array}{l}\text { Michigan; 1989; MMACS; } 275 \text { FP } \\
\text { and } 60 \text { private NFP homes }\end{array}$ & $\begin{array}{l}\text { Severity of illness (ADLs), payment status (\% Medicaid } \\
\text { patient days), dementia (\% of residents with cognitive } \\
\text { deficiencies) }\end{array}$ & None \\
\hline $\begin{array}{l}\text { Johnson-Pawlson and } \\
\text { Infeld } 1996^{\text {w13 }}\end{array}$ & $\begin{array}{l}\text { Maryland; } 1991-2 \text {; OSCAR; } 137 \text { FP } \\
\text { and } 55 \text { private NFP homes }\end{array}$ & $\begin{array}{l}\text { Severity of illness (ADLs), payment status } \\
\text { (\% of residents covered by Medicare) }\end{array}$ & $\begin{array}{l}\text { Staffing (RN and full time equivalent nurse } \\
\text { positions/patient) }\end{array}$ \\
\hline $\begin{array}{l}\text { Spector and Fortinsky } \\
1998^{\text {w14 }}\end{array}$ & Ohio; 1994; MDS; 843 homes & Age, dementia (cognitive performance) & None \\
\hline Spector et al $1998^{\mathrm{w} 15}$ & $\begin{array}{l}\text { United States; } 1987 ; \text { NMES; } 1695 \text { FP } \\
\text { and } 535 \text { private NFP homes }\end{array}$ & Age, dementia, payment status (Medicaid coverage \%) & None \\
\hline Hughes et al $2000^{\mathrm{w} 16}$ & $\begin{array}{l}\text { Continental United States; 1997; OSCAR; } 10666 \text { FP } \\
\text { and } 3342 \text { private NFP homes }\end{array}$ & Dementia, payment status & $\begin{array}{l}\text { Staffing (in facility model), } \\
\text { antidepressant drug use }\end{array}$ \\
\hline Troyer $2001^{\text {w17 }}$ & Florida; 1994-6; OSCAR; unclear & Payment status (private pay/Medicaid/Medicare funding) & None \\
\hline Chou $2002^{\text {w18 }}$ & $\begin{array}{l}\text { United States; } 1984-94 ; \text { NLTCS; } 1770 \text { FP } \\
\text { and } 1044 \text { private NFP residents }\end{array}$ & $\begin{array}{l}\text { Age, severity of illness (ADLs, before admission), } \\
\text { dementia (cognitive score on admission) }\end{array}$ & None \\
\hline $\begin{array}{l}\text { Harrington et al } \\
2002^{\text {w19 }}\end{array}$ & $\begin{array}{l}\text { United States; } 1997-8 \text {; OSCAR; } 9009 \text { FP } \\
\text { and } 3789 \text { private NFP homes }\end{array}$ & $\begin{array}{l}\text { Severity of illness (ADLs), dementia (in secondary analysis } \\
\text { only), payment status (\% Medicaid residents) }\end{array}$ & None \\
\hline $\begin{array}{l}\text { Grabowski and Hirth } \\
2003^{\text {w20 }}\end{array}$ & $\begin{array}{l}\text { United States; } 1995 \text {; OSCAR; } 11174 \text { FP } \\
\text { and } 4688 \text { private NFP homes }\end{array}$ & Severity of illness (ADLs), payment status & None \\
\hline Berta et al $2004^{\mathrm{w} 21}$ & Ontario; 1996-2002; RCFS; not clear & Unadjusted analysis & Unadjusted analysis \\
\hline $\begin{array}{l}\text { Grabowski and } \\
\text { Angelelli } 2004^{\text {w22 }}\end{array}$ & $\begin{array}{l}\text { United States; } 1998-2000 \text {; OSCAR and MDS; } 9478 \text { FP a } \\
\text { nd } 3434 \text { private NFP homes }\end{array}$ & $\begin{array}{l}\text { Adjusted analysis but none of } 4 \text { selected appropriate } \\
\text { factors included }\end{array}$ & None \\
\hline $\begin{array}{l}\text { Grabowski and Castle } \\
2004^{\text {w23 }}\end{array}$ & $\begin{array}{l}\text { United States; 1991-9; OSCAR; } 18432 \text { homes, selecting } \\
\text { those with } 5 \text { consecutive yearly assessments with upper } \\
\text { and lower quartile scores for each quality measure }\end{array}$ & Unadjusted analysis & Unadjusted analysis \\
\hline Grabowski $2004^{\text {w24 }}$ & $\begin{array}{l}\text { Continental United States; 1996; MEPS and OSCAR; } \\
815 \text { homes, with } 1856 \text { FP and } 673 \text { private NFP residents }\end{array}$ & Age, severity of illness (ADLs), dementia, payment status & None \\
\hline $\begin{array}{l}\text { Grabowski et al } \\
2004^{\text {w25 }}\end{array}$ & $\begin{array}{l}\text { United States; } 1998-9 ; \text { MDS and OSCAR; } 15128 \text { homes } \\
\text { (13 } 819 \text { for daily pain information, } 13169 \text { for pressure } \\
\text { ulcer information, } 13859 \text { for physical restraint } \\
\text { information) }\end{array}$ & $\begin{array}{l}\text { Adjusted analysis but none of } 4 \text { selected appropriate } \\
\text { factors included }\end{array}$ & None \\
\hline $\begin{array}{l}\text { Konetzka et al } \\
2004^{\text {w26 }}\end{array}$ & $\begin{array}{l}\text { United States; 1996-2000; OSCAR; } 11968 \text { FP } \\
\text { and } 5077 \text { private NFP homes }\end{array}$ & $\begin{array}{l}\text { Severity of illness (ADLs), dementia (\% with), } \\
\text { payment status (\% private pay) }\end{array}$ & None \\
\hline $\begin{array}{l}\text { Konetzkaet al } \\
2004^{\text {w27 }}\end{array}$ & $\begin{array}{l}\text { United States; } 1996 \text {; MEPS; } 529 \text { FP } \\
\text { and } 192 \text { private NFP residents }\end{array}$ & $\begin{array}{l}\text { Severity of illness (ADL dependence), dementia (cognitive } \\
\text { performance), payment status (payer source) }\end{array}$ & $\begin{array}{l}\text { Staffing (RNs and LPNs/100 residents, } \\
\text { nursing assistants/100 residents }\end{array}$ \\
\hline
\end{tabular}




\begin{tabular}{|c|c|c|c|}
\hline \multirow[b]{2}{*}{ Study } & \multirow[b]{2}{*}{$\begin{array}{l}\text { Place; year; data source*; } \\
\text { No of residents or nursing homes }\end{array}$} & \multicolumn{2}{|c|}{ Factors controlled or adjusted for } \\
\hline & & $\begin{array}{l}\text { Appropriate: age, severity of illness, severity of } \\
\text { dementia, and payment status adjustments }\end{array}$ & $\begin{array}{l}\text { Inappropriate: quality measures used in } \\
\text { other studies; measures of intensity of care }\end{array}$ \\
\hline $\begin{array}{l}\text { Lapane and Hughes } \\
2004^{\text {w28 }}\end{array}$ & $\begin{array}{l}\text { Ohio; } 1997 \text { and 2000; MDS; } 390 \text { FP and } 109 \text { private NFP in } \\
\text { 1997; } 391 \text { FP and } 114 \text { private NFP homes in } 2000\end{array}$ & $\begin{array}{l}\text { Age, dementia, payment status (\% of residents with } \\
\text { Medicaid/Medicare) }\end{array}$ & None \\
\hline $\begin{array}{l}\text { Lapane and Hughes } \\
2004^{\text {w29 }}\end{array}$ & $\begin{array}{l}\text { IL, MA, MS, NY, OH, and SD; 2000; MDS and OSCAR; } \\
1560 \text { FP and } 494 \text { private NFP homes }\end{array}$ & $\begin{array}{l}\text { Age, dementia (cognitive functioning), payment status } \\
\text { (\% of residents being paid for by Medicare/Medicaid) }\end{array}$ & $\begin{array}{l}\text { Staffing (RN and LPN full time equivalents, } \\
\text { and nursing assistants per } 100 \text { beds) }\end{array}$ \\
\hline Rantz et al $2004^{\text {w30 }}$ & $\begin{array}{l}\text { Missouri; } 2000-1 \text {; MDS and research nurses; } \\
60 \text { FP and } 26 \text { private NFP homes }\end{array}$ & Unadjusted analysis & Unadjusted analysis \\
\hline $\begin{array}{l}\text { Zhang and Grabowski } \\
2004^{\text {w31 }}\end{array}$ & $\begin{array}{l}\text { United States; 1987-MMACS, 1993-OSCAR; } 5092 \\
\text { facilities for matched analysis between the } 2 \text { years }\end{array}$ & $\begin{array}{l}\text { Severity of illness (ADL score), payment status } \\
\text { (proportion Medicare funded) }\end{array}$ & None \\
\hline $\begin{array}{l}\text { Akinci and } \\
\text { Krolikowski } 2005^{\text {w32 }}\end{array}$ & $\begin{array}{l}\text { Northeastern Pennsylvania; 2000-2; OSCAR; } 46 \text { FP homes } \\
\text { and } 38 \text { private NFP homes }\end{array}$ & Unadjusted analysis & Unadjusted analysis \\
\hline $\begin{array}{l}\text { Bardenheier et al } \\
2005^{\mathrm{w} 33}\end{array}$ & $\begin{array}{l}\text { United States; 1995, 1997, and 1999; NNHS; } \\
1409 \text { homes in 1995, } 1488 \text { in 1997, and } 1423 \text { in } 1999\end{array}$ & Age, payment status (payment source) & None \\
\hline Zinn et al $2005^{\text {w34 }}$ & $\begin{array}{l}\text { United States; 2002-3; MDS; } 10763 \text { FP, } 4802 \text { private NFP, } \\
994 \text { public }\end{array}$ & $\begin{array}{l}\text { Adjusted analysis but none of } 4 \text { selected appropriate } \\
\text { factors included }\end{array}$ & None \\
\hline
\end{tabular}

ADLs=activities of daily living; LPN=licensed practical nurse; FP=for-profit; NFP=not-for-profit; RN=registered nurse.

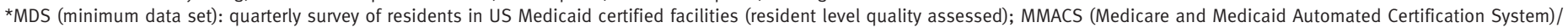

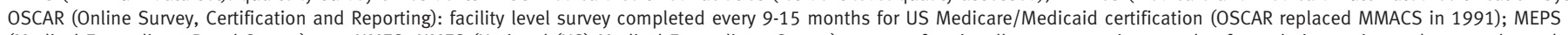

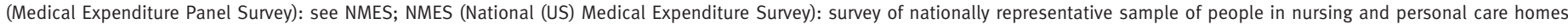
and facilities for mentally challenged people (collects information on health expenditures); NLTCS (National (US) Long Term Care Survey): survey of nationally representative sample of elderly, disabled, Medicaid beneficiaries in community or institutional settings (tracks expenditures, family caregiving, and Medicaid service use); NNHS (National (US) Nursing Home

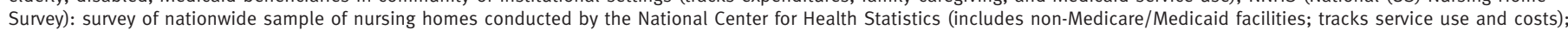
OSCAR: see MMACS; RCFS (Residential Care Facilities Survey): Statistics Canada census of residential care facilities.

adjustment explained heterogeneity. Disagreements were resolved by consensus, with consultation of a third investigator when resolution could not be achieved.

\section{Statistical analysis}

Many studies had for-profit versus not-for-profit comparisons including multiple measures of quality of care. When summarising results, we classified studies into three categories. (1) "All statistically significant differences favoured one ownership type"-studies fulfilled two requirements: at least one outcome with $\mathrm{P}<0.05$ favoured either for-profit or not-for-profit and all outcomes with $\mathrm{P}<0.05$ favoured the same funding structure (that is, all favour not-for-profit or all favour for-profit). (2) "Most but not all significant differences favoured one ownership type"-studies fulfilled two requirements: at least four quality measures had $\mathrm{P}<0.05$ and three times as many outcomes with $\mathrm{P}<0.05$ favour one ownership as favour the other. (3) "Mixed results"- all other results.

We pooled outcomes by using random effects models separately for the most frequently used quality of care measures: number of staff or level of training of staff, pressure ulcers, physical restraints, and regulatory (government survey) deficiencies. We considered $\mathrm{P}<0.05$ to be statistically significant.

We used prevalence, rather than incidence, in reporting physical restraint use and pressure ulcers based on authors' reporting of study outcomes. We report the odds ratios and 95\% confidence intervals for these outcomes. When necessary, we converted other effect measures to odds ratios by using available data. For example, if the study reported a relative risk (RR) and the event proportion in for-profit nursing homes $\left(\mathrm{P}_{\mathrm{fp}}\right)$, the odds ratios was calculated as $(\mathrm{RR} \times$ $\left.\left(1-\mathrm{P}_{\mathrm{fp}}\right)\right) /\left(1-\mathrm{P}_{\mathrm{fp}} \times \mathrm{RR}\right)$. Similarly, when the studies presented a $\beta$ coefficient (an adjusted result representing difference in event proportions in for-profit and not-for-profit nursing homes, $\mathrm{P}_{\mathrm{fp}}-\mathrm{P}_{\mathrm{nfp}}$ ), if the event proportion $(\mathrm{Pc})$ in the study population and sample sizes $\left(\mathrm{N}_{\mathrm{fp}}\right.$ and $\left.\mathrm{N}_{\mathrm{nfp}}\right)$ of the nursing homes in for-profit and not-for-profit were provided, solving the following two equations for $\mathrm{P}_{\mathrm{nfp}}$ and $\mathrm{P}_{\mathrm{fp}}$, we computed the odds ratio: $\mathrm{P}_{\mathrm{fp}}-\mathrm{P}_{\mathrm{nfp}}=\beta$ and $\left(\mathrm{P}_{\mathrm{fp}} \times \mathrm{N}_{\mathrm{fp}}+\mathrm{P}_{\mathrm{nfp}} \times \mathrm{N}_{\mathrm{nfp}}\right) /\left(\mathrm{N}_{\mathrm{fp}}+\mathrm{N}_{\mathrm{nfp}}\right)$ $=\mathrm{Pc}$. For the outcomes of deficiencies and staffing, we used the ratio of the effect from not-for-profit to forprofit nursing homes in pooling studies.

We avoided repetition of data on the same resident from different studies by preferentially using data from the larger dataset when necessary. One author (GHG) made these decisions by using blinded copies of articles while unaware of study outcomes. We requested supplemental data when available data was insufficient for analysis. We evaluated heterogeneity with both a $\chi^{2}$ test and the $\mathrm{I}^{2}$ statistic, interpreting a low $\mathrm{I}^{2}$ as $25 \%$ or lower and a high $\mathrm{I}^{2}$ as $75 \%$ or higher. ${ }^{29}$ We examined funnel plots for evidence of publication bias. We applied a univariate meta-regression random effects model to each pooled outcome to evaluate potential sources of heterogeneity.

\section{Hypotheses to explain heterogeneity}

Our a priori hypotheses for sources of potential heterogeneity included analysis of privately owned and publicly owned nursing facilities in the same category, appropriate and inappropriate adjustments, the year of data collection, geography and political environment, and primary compared with secondary data collection. We did univariate meta-regression for each potential cause of heterogeneity. We present subgroup results if the likelihood of the differences between subgroups being due to chance was $\mathrm{P}<0.10$. Our a priori 
Table 4 Q Quality of care measures and outcomes of studies comparing private for-profit and private not-for-profit nursing homes (favoured directions represent those with higher quality care)

Study Quality measure

\section{Outcome}

$\begin{array}{ll}\text { Levey et al } 1973^{\text {w1 }} & \begin{array}{l}\text { Dietary options; doctor's order book showing activity; nursing kardex showing } \\ \text { activity; activities for patients' availability (religious, recreation); patients' records }\end{array}\end{array}$ Mixed results: not significant for all measures (direction not noted) being complete; personal care availability; physical plant utilities; restorative services availability; staffing — No of nursing shifts not covered per week, licensed nursing hours, total nursing hours

\begin{tabular}{|c|c|}
\hline $\begin{array}{l}\text { Cohen and Dubay } \\
1990^{\text {w2 }}\end{array}$ & Staffing: RNs, LPNs per bed \\
\hline Elwell $1984^{\mathrm{w3}}$ & $\begin{array}{l}\text { Multi-bed rooms (proportion of patients in them); staffing_allied health hours/ } \\
\text { resident/day, nursing hours/resident/day, physician hours/resident/week, RN } \\
\text { hours/resident/day }\end{array}$ \\
\hline Lee $1984^{\text {w4 }}$ & $\begin{array}{l}\text { Nursing and personal care delivery index (by inspection and resident interviews } \\
\text { on } 17 \text { items); quarterly care review completion; residents' satisfaction by }\end{array}$ \\
\hline
\end{tabular}
interview; room conditions ratings by inspection; staffing—staff/resident ratio

\section{Wiesbrod and Deficiencies in Wisconsin licensing survey}

Schlesinger $1986^{\mathrm{w} 5}$

Lemke and Moos Service availability; staff richness; staffing—No of full time equivalent staff $1989^{\text {w6 }} \quad$ members/resident; subjective comfort; subjective control; subjective rapport; subjective resident autonomy; subjective security

Pearson et al $1992^{\mathrm{w} 7}$ Freedom of choice; healthcare treatment; home-like environment; privacy and dignity; social independence; variety of experience

Graber $1993^{\text {w8 }} \quad$ Deficiencies in OSCAR; ombudsman office complaints

Mixed results: non-significantly favoured private NFP

Most significant comparisons favoured private NFP: having fewer multi-bed rooms favoured FP ( $\mathrm{P}<0.001)$; all other measures favoured private NFP ( $<<0.025)$

Mixed results: resident satisfaction by interview and room conditions by inspection favoured FP (P<0.05); favoured private NFP for quarterly care review completion and staffing; non-significantly favoured private NFP for nursing and personal care delivery $(P=0.077)$

Mixed results: non-significantly favoured private NFP for church owned homes; non-significantly favoured FP for non-church owned ( $P<0.1)$

All significant ( $\mathrm{P}<0.05)$ comparisons favoured private NFP: only significant difference was for subjective rapport, which favoured private NFP; private NFP also offered more comfortable physical environment and more health services

All significant ( $\mathrm{P}<0.05)$ comparisons favoured private NFP: non-significantly favoured private NFP for having healthcare treatment, privacy, and dignity; favoured private NFP for all others

All significant ( $\mathrm{P}(0.05)$ comparisons favoured private NFP: non-significantly favoured private NFP overall; non-significantly favoured private NFP for deficiencies, but significantly favoured private NFP for complaints ( $\mathrm{P}<0.01)$

Aaronson et al Pressure ulcer prevalence; restraint use prevalence; staffing-RNs, LPNs, and $1994^{\mathrm{w} 9}$ aides per 100 beds

Moseley $1994^{\mathrm{w10}} \quad$ Composite measure of inappropriate care (underprovision of routine medical care, skilled nursing care, and physical therapy or overprovision of psychotropic drugs, physical restraints, or urinary catheterisation); functional improvement over 9 months

Sainfort et al $1995^{\text {w11 }}$ Outcome based quality such as grooming, mood, awareness of condition, physical condition, promotion of family ties, continuity of lifestyle; process based quality such as plan of care, medical records, planning and evaluation, admission/transfer, residents' influence, staff's attitudes to residents, staff communication, communication between residents, variety/adequacy of activities, match of residents to activities, volunteer programme, meal variety/ presentation, nutrition/diet

Holmes $1996^{\text {w12 }}$ Deficiencies in MMACS per facility

Johnson-Pawlson and Deficiencies in Long-Term Care Survey

Infeld $1996^{\text {w13 }}$

Spector and Fortinsky Pressure ulcer prevalence

$1998^{\text {w14 }}$

Spector et al $1998^{\text {w15 }}$ Functional disability at year end; hospital admission incidence; infection prevalence; mortality during 1987; pressure ulcer prevalence

Psychotropic drug use (use is poorer quality than no use); deficiencies in OSCAR
per resident day; staffing - No of RN hours/day, total No of nursing hours per patient day

\begin{tabular}{ll}
\hline Troyer $2001^{\text {w17 }}$ & Deficiencies in OSCAR per resident day \\
\hline Chou $2002^{\text {w18 }}$ & Mortality; prevalence of dehydration, pressure ulcers, and urinary tract infection
\end{tabular}

Harrington et al $2002^{\text {w19 }}$ Deficiencies in OSCAR (quality care)*; staffing—(RN + LVN/LPN hours)/resident day and nursing assistant hours/resident day

Grabowski and Hirth Prevalence of feeding tube, pressure ulcers, restraint use, and urinary $2003^{\mathrm{w} 20}$ catheterisation; staffing-proportion of total staff who are RNs, total nurse staff/ resident/day

Berta et al $2004^{\mathrm{w} 21}$ Staffing-RN + nursing assistant hours/resident/day, other direct care staff hours/resident/day

Grabowski and Pain reported by residents; pressure ulcer prevalence; restraint use prevalence Angelelli $2004^{\text {w22 }}$

Grabowski and Castle Prevalence of feeding tube, pressure ulcers, restraint use, and urinary $2004^{\text {w23 }}$ catheterisation

Grabowski $2004^{\text {w24 }}$ Deficiencies in health/quality of care in OSCAR

Mixed results: favoured FP for pressure ulcer (P<0.05); favoured private NFP for staffing ( $(P<0.05)$; non-significantly favoured private NFP for restraint use

All significant ( $\mathrm{P}<0.05)$ comparisons favoured private NFP: favoured private NFP (P<0.001) for composite measure; non-significantly favoured private NFP for functional improvement

Mixed results: non-significantly favoured private NFP for outcome measures; difference not stated for process measures

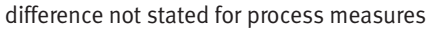




\begin{tabular}{|c|c|c|}
\hline Study & Quality measure & Outcome \\
\hline $\begin{array}{l}\text { Grabowski et al } \\
2004^{\text {w25 }}\end{array}$ & Pressure ulcer prevalence & Favoured private NFP $(\mathrm{P}<0.05)$ \\
\hline $\begin{array}{l}\text { Konetzka et al } \\
2004^{\text {w26 }}\end{array}$ & $\begin{array}{l}\text { Deficiencies in OSCAR; staffing_nursing assistant hours/resident day, RN hours/ } \\
\text { resident day, RN + LPN hours/resident day }\end{array}$ & All significant $(P<0.05)$ comparisons favoured private NFP \\
\hline $\begin{array}{l}\text { Konetzka et al } \\
2004^{\mathrm{w} 27}\end{array}$ & Transfer to hospital rate for patients with pneumonia & Favoured private NFP $(\mathrm{P}<0.01)$ \\
\hline $\begin{array}{l}\text { Lapane and Hughes } \\
2004^{\mathrm{w} 28}\end{array}$ & $\begin{array}{l}\text { Depression treatment prevalence-assessed by antidepressant use and } \\
\text { specifically by SSRI use }\end{array}$ & Non-significantly favoured FP for both measures \\
\hline $\begin{array}{l}\text { Lapane and Hughes } \\
2004^{\text {w29 }}\end{array}$ & $\begin{array}{l}\text { Depression treatment prevalence-assessed by antidepressant use and } \\
\text { specifically by use of antidepressants other than tricyclic antidepressants }\end{array}$ & $\begin{array}{l}\text { All significant }(P<0.05) \text { comparisons favoured private NFP: favoured private NFP } \\
(P<0.05) \text { for antidepressant use, and non-significantly favoured private NFP for not } \\
\text { using tricyclic antidepressants }\end{array}$ \\
\hline Rantz et al $2004^{\text {w30 }}$ & Performance on MDS quality indicators, confirmed by research nurses & Non-significantly favoured private NFP \\
\hline $\begin{array}{l}\text { Zhang and Grabowski } \\
2004^{\text {w31 }}\end{array}$ & Prevalence of pressure ulcers, restraint use, and urinary catheterisation & $\begin{array}{l}\text { All significant }(\mathrm{P}<0.05) \text { comparisons favoured private NFP: favoured private NFP for } \\
\text { all measures }(\mathrm{P}<0.001) \text { except restraint use prevalence, which non-significantly } \\
\text { favoured private NFP }\end{array}$ \\
\hline $\begin{array}{l}\text { Akinci and } \\
\text { Krolikowski } 2005^{\text {w32 }}\end{array}$ & $\begin{array}{l}\text { Deficiencies in quality of care in Pennsylvania database; staffing-certified } \\
\text { nursing assistant hours/day, LPN/LVN hours/day, RN hours/day, total staff } \\
\text { hours/day }\end{array}$ & $\begin{array}{l}\text { All significant ( } \mathrm{P}<0.05) \text { comparisons favoured private NFP: non-significantly } \\
\text { favoured private NFP ( } \mathrm{P}<0.05) \text { for deficiencies, certified nursing assistant hours, } \\
\text { and LPN/LVN hours; favoured private NFP for RN hours and total staff hours }\end{array}$ \\
\hline $\begin{array}{l}\text { Bardenheier et al } \\
2005^{\mathrm{w} 33}\end{array}$ & Vaccination for pneumococcus (\% of homes) & Non-significantly favoured private NFP \\
\hline Zinn et al $2005^{\text {w34 }}$ & $\begin{array}{l}\text { Prevalence of infection, pain, pressure ulcers, pressure ulcers adjusted for facility } \\
\text { admission profile or loss of ADLs, and restraint use }\end{array}$ & $\begin{array}{l}\text { Mixed results: favoured private NFP }(P<0.1) \text { for all measures except pain } \\
\text { prevalence, which favoured FP }(P<0.01)\end{array}$ \\
\hline
\end{tabular}

hypotheses to explain heterogeneity are detailed below.

Analysing privately and publicly-owned not-for-profit facilities in the same category-We hypothesised that privately owned not-for-profit facilities may deliver superior care compared with publicly owned facilities, and thus comparisons between not-for-profit and forprofit facilities may yield different results if publicly owned facilities are included, as seen in previous studies. ${ }^{19}$ We decided, a priori, to present the result of a for-profit versus privately owned not-for-profit metaanalysis separately from a for-profit versus not-forprofit meta-analysis regardless of whether privately or publicly owned not-for-profit status explained heterogeneity of the pooled estimate.

Extent of appropriate and inappropriate adjustment - We have defined concepts of appropriate and inappropriate adjustment in the data extraction section above. We compared studies with above median scores against those with scores below the median for assessment of appropriateness. Similarly, we compared studies with inappropriate adjustment against those without inappropriate adjustment, excluding studies that did not have an adjusted analysis.

Year of data collection - Legislation on quality of care in nursing homes was introduced in the United States under the Federal Nursing Home Reform Act (part of Omnibus Budget Reconciliation, 1987). Most of the studies we reviewed were from the United States. As a result, we compared data collected before and during 1987 versus after 1987.

Geography-We compared data collected inside and outside the United States, as geography and political environment are potential sources of heterogeneity.
Primary versus secondary data collection -We compared data acquired by primary (direct) data collection with those acquired by secondary (administrative agency) data collection.

\section{RESULTS}

Of the 8827 articles screened, we selected 956 for blinded full text review. Figure 1 details the steps in this review. Our agreement on the eligibility of studies was very good ( $\kappa=0.73$ on the basis of two questions: does the study evaluate nursing homes, and does the study compare quality of care in for-profit and not-forprofit facilities?). Disagreements stemmed from implied but not stated definitions in the articles regarding good and poor quality and implied but not stated quality of care measures. We requested supplementary data from 36 authors; 25 responded, of whom three did new analyses in response to our queries.

We found 82 studies, spanning 1965 to 2003, comparing for-profit and not-for-profit nursing homes. ${ }^{\text {w1- }}$ w82 We found 40 studies in which all statistically significant analyses $(\mathrm{P}<0.05)$ favoured not-for-profit homes and three in which all statistically significant analyses favoured for-profit homes. Similarly, 34 studies compared for-profit and privately owned not-for-profit nursing homes. In 16 of these, all statistically significant comparisons favoured higher quality in privately owned not-for-profit homes; none had all statistically significant analyses favouring higher quality in forprofit homes.

Tables 1 and 2 present a summary of the characteristics and outcomes of all studies included in this review and summarise the results of comparisons for quality measures evaluated by three or more studies. Tables 3 and 4 present the detailed study characteristics and 
Table 5 | Characteristics of studies comparing for-profit and not-for-profit nursing home quality of care (public and private NFP homes)

\begin{tabular}{|c|c|c|c|}
\hline \multirow[b]{2}{*}{ Study } & \multirow[b]{2}{*}{$\begin{array}{l}\text { Place; year; data source*; No of residents } \\
\text { or nursing homes }\end{array}$} & \multicolumn{2}{|c|}{ Factors controlled or adjusted for } \\
\hline & & $\begin{array}{l}\text { Appropriate: age, severity of illness, severity of } \\
\text { dementia, and payment status adjustments }\end{array}$ & $\begin{array}{l}\text { Inappropriate: quality measures used in other studies; } \\
\text { measures of intensity of care }\end{array}$ \\
\hline Winn $1974^{\text {w35 }}$ & $\begin{array}{l}\text { Washington state; } 1971 \text {; mailed questionnaire to } \\
\text { administrators; } 24 \text { FP, } 24 \text { NFP }\end{array}$ & Unadjusted analysis & Unadjusted analysis \\
\hline $\begin{array}{l}\text { Riporttella-Muller } \\
\text { and Slesinger } \\
1982^{\text {w36 }}\end{array}$ & $\begin{array}{l}\text { Wisconsin; July 1977-June 1978; Wisconsin Department } \\
\text { of Health and Wisconsin Nursing Homes Ombudsman } \\
\text { Program; } 462 \text { homes }\end{array}$ & $\begin{array}{l}\text { Adjusted analysis but none of } 4 \text { selected appropriate } \\
\text { factors included }\end{array}$ & None \\
\hline Nyman $1984^{\text {w37 }}$ & $\begin{array}{l}\text { Wisconsin; 1978-9; } 1979 \text { Wisconsin Nursing Home } \\
\text { Survey, Quality Assurance Project Pre-test, and Cost- } \\
\text { Quality Study dataset; } 88 \text { cases of nursing home } \\
\text { violations (No of nursing homes not indicated) }\end{array}$ & $\begin{array}{l}\text { Payment source; severity of illness (need for } \\
\text { intermediate, personal, or residential care by payment } \\
\text { source) }\end{array}$ & None \\
\hline $\begin{array}{l}\text { Brunetti et al } \\
1990^{\text {w38 }}\end{array}$ & $\begin{array}{l}\text { North Carolina; 1987; surveys to nursing home } \\
\text { administrators; } 236 \text { nursing homes (164 FP, } 40 \text { NFP) }\end{array}$ & $\begin{array}{l}\text { Certification (Medicare only, Medicaid only, or Medicare } \\
\text { and Medicaid) }\end{array}$ & None \\
\hline Munroe $1990^{\text {w39 }}$ & $\begin{array}{l}\text { California; } 3 \text { December } 1985 \text { to } 30 \text { December 1986; } \\
\text { Office of Statewide Health Planning and Development of } \\
\text { California; } 455 \text { homes }\end{array}$ & Illness severity (ADLs/IADLs); payment status & $\begin{array}{l}\text { Proportions of residents with catheters and decubiti; ratio } \\
\text { of RN to LVN hours per resident day }\end{array}$ \\
\hline Cherry $1991^{\text {w40 }}$ & $\begin{array}{l}\text { Missouri; 1984; Missouri State Board of Health; } 134 \\
\text { homes }\end{array}$ & Payment status & RN, LPN, aide hours per resident \\
\hline $\begin{array}{l}\text { Kanda and Mezey } \\
1991^{\text {w41 }}\end{array}$ & $\begin{array}{l}\text { Pennsylvania; 1980, 1982, 1985, 1987; Long Term Care } \\
\text { Facilities Survey conducted by State Health Data Center, } \\
\text { Pennsylvania Department of Health; } 407 \text { homes for } \\
\text { 1980, } 395 \text { for } 1982,395 \text { for } 1985,461 \text { for } 1987\end{array}$ & $\begin{array}{l}\text { Age of residents (in RN staffing comparison, when each } \\
\text { year was analysed separately) }\end{array}$ & None \\
\hline Cherry $1993^{\text {w42 }}$ & $\begin{array}{l}\text { Missouri; 1984; Missouri Division of Aging Routine } \\
\text { Inspections and Missouri State Board of Health; } 210 \\
\text { nursing homes }\end{array}$ & $\begin{array}{l}\text { Adjusted analysis but none of } 4 \text { selected appropriate } \\
\text { factors included }\end{array}$ & Nurse ratio \\
\hline Zinn et al $1993^{\text {w43 }}$ & $\begin{array}{l}\text { Pennsylvania; 1987; MMACS, Pennsylvania Long Term } \\
\text { Care Facility Questionnaire; } 438 \text { homes }\end{array}$ & Payment status & RNs per resident \\
\hline Zinn $1993^{\text {w44 }}$ & $\begin{array}{l}46 \text { continental US states; } 1987 ; \text { AHCA and MMACS; } \\
\text { approximately } 14000 \text { homes }\end{array}$ & $\begin{array}{l}\% \text { private pay; } \% \text { confused; } \% \text { Medicare; functional } \\
\text { severity index }\end{array}$ & $\begin{array}{l}\text { RN, LPN, aide staffing; rate of catheter use, restraint use, } \\
\text { and tube feeding }\end{array}$ \\
\hline $\begin{array}{l}\text { Graber and Sloane } \\
1995^{\text {w45 }}\end{array}$ & $\begin{array}{l}\text { North Carolina; 1991; OSCAR, North Carolina Division of } \\
\text { Medical Assistance, Office of State Health Planning; } 195 \\
\text { homes }\end{array}$ & $\begin{array}{l}\text { Illness severity (\% intubated patients, facility disability } \\
\text { level, \% with incontinent residents) }\end{array}$ & $\begin{array}{l}\text { RN ratio; LVN/nursing assistant ratio; \% of residents on } \\
\text { psychotropic drugs }\end{array}$ \\
\hline $\begin{array}{l}\text { Christensen and } \\
\text { Beaver } 1996^{\text {w46 }}\end{array}$ & $\begin{array}{l}\text { Oregon; 1991-4; Oregon Board of Examiners of Nursing } \\
\text { Home Administrators and State surveyors reports; } 147 \\
\text { nursing homes ( } 37 \text { NFP or government and } 110 \text { FP) }\end{array}$ & Unadjusted analysis & Unadjusted analysis \\
\hline Mukamel $1997^{\text {w47 }}$ & $\begin{array}{l}\text { New York (excluding New York City); } 1986-90 \text {; New York } \\
\text { State Department of Health; approximately } 550 \text { homes, } \\
42.3 \% \text { of residents in proprietary homes, } 39.9 \% \text { of } \\
\text { residents in voluntary NFP homes, } 17.8 \% \text { in public homes }\end{array}$ & Unadjusted analysis & Unadjusted analysis \\
\hline $\begin{array}{l}\text { Anderson et al } \\
1998^{\text {w48 }}\end{array}$ & $\begin{array}{l}\text { Texas; 1990; Texas Medicare Nursing Facility Cost } \\
\text { Reports and Client Assessment, Review, and Evaluation } \\
\text { form; } 494 \text { nursing homes }\end{array}$ & $\%$ of private pay & RN, LPN, aide staffing \\
\hline $\begin{array}{l}\text { Bliesmer et al } \\
1998^{\text {w49 }}\end{array}$ & $\begin{array}{l}\text { Minnesota; 1988-91; Minnesota Department of Human } \\
\text { Services Long-Term Care Division facility profiles and } \\
\text { assessments of residents by RNs; } 4103 \text { residents in } \\
\text { 1988, } 4676 \text { residents in 1989, and } 4672 \text { residents in } \\
1990\end{array}$ & Age & Compliance with regulations \\
\hline $\begin{array}{l}\text { Castle and Fogel } \\
1998^{\text {w50 }}\end{array}$ & United States; 1995; OSCAR, ARF; 15074 homes & $\begin{array}{l}\text { Illness severity (ADLs, incontinent bladder/bowel); } \\
\text { payment status }\end{array}$ & $\begin{array}{l}\text { Psychotropic drug use; staffing (high/medium/low RNs, } \\
\text { LPNs, nursing assistants per resident) }\end{array}$ \\
\hline $\begin{array}{l}\text { Anderson and } \\
\text { Lawhorne } \\
1999^{\text {w51 }}\end{array}$ & $\begin{array}{l}\text { Advance care directive prevalence; feeding tube } \\
\text { prevalence; drug errors noted on survey; pressure ulcer } \\
\text { prevalence; restraint use prevalence; staffing-direct } \\
\text { care hours per resident per day; urinary catheterisation } \\
\text { prevalence }\end{array}$ & $\begin{array}{l}\text { All significant ( } \mathrm{P}<0.05) \text { comparisons favoured NFP: non- } \\
\text { significantly favoured NFP for drug errors, non- } \\
\text { significantly favoured FP for restraint use prevalence; } \\
\text { favoured NFP for all other comparisons }\end{array}$ & None \\
\hline $\begin{array}{l}\text { Bravo et al } \\
1999^{\text {w5 }}\end{array}$ & $\begin{array}{l}\text { Eastern townships of Quebec (Canada); 1996; resident } \\
\text { interviews; } 301 \text { residents from } 88 \text { nursing homes }\end{array}$ & $\begin{array}{l}\text { Age; cognitive functioning (MMMS score); functional } \\
\text { autonomy (SMAF score) }\end{array}$ & Staff to resident ratio \\
\hline Castle $1999^{\text {w53 }}$ & $\begin{array}{l}\text { CA, CT, IA, MD, MA, OH OR, TN, TX, and VA: } 1990 \text { and } \\
\text { 1993, Resident Assessment Instrument and OSCAR; } 268 \\
\text { facilities ( } 90 \% \text { in each cohort FP) }\end{array}$ & $\begin{array}{l}\text { Age; ADLs; severity of illness; severity of dementia; } \\
\text { payment status }\end{array}$ & Staffing levels \\
\hline Ballou $2000^{\text {w54 }}$ & $\begin{array}{l}\text { Wisconsin; 1987-95; Wisconsin Centre for Health } \\
\text { Statistics and Wisconsin Bureau of Quality Assurance }\end{array}$ & Unadjusted analysis & Unadjusted analysis \\
\hline Castle $2000^{\text {w55 }}$ & United States; 1997; OSCAR; 17024 homes & Dementia; ADLs & $\begin{array}{l}\text { Staffing (RNs, LPNs, nurse aides, specialists per resident } \\
\text { and nurse aide training); pressure ulcer incidence; urinary } \\
\text { catheterisation; use of psychoactive drugs }\end{array}$ \\
\hline Castle $2000^{\text {w5 }}$ & $\begin{array}{l}\text { United States; } 1992 \text { and 1997; OSCAR; } 15455 \text { homes in } \\
\text { 1992; } 16533 \text { homes in } 1997\end{array}$ & ADLs; payment status & $\begin{array}{l}\text { Staffing (RNs, LPNs, nurse aides, rehabilitation assistants } \\
\text { per } 100 \text { beds); antipsychotic drug use; residents with } \\
\text { psychiatric problems }\end{array}$ \\
\hline Castle $2001^{\text {w57 }}$ & $\begin{array}{l}\text { United States; 1999; OSCAR; } 420 \text { nursing facilities and } \\
\text { OSCAR } 1999 \text { ( 16 } 000 \text { homes) }\end{array}$ & ADLs; dementia; payment status & $\begin{array}{l}\text { Catheterisation; psychoactive drug use; physical restraint } \\
\text { use; pressure ulcers; psychological disorders }\end{array}$ \\
\hline Castle $2001^{\text {w58 }}$ & United States; 1997; OSCAR; 16871 homes & Age; ADLs & None \\
\hline
\end{tabular}


Factors controlled or adjusted for

\begin{tabular}{|c|c|c|c|}
\hline \multirow[b]{2}{*}{ Study } & \multirow[b]{2}{*}{$\begin{array}{l}\text { Place; year; data source*; No of residents } \\
\text { or nursing homes }\end{array}$} & \multicolumn{2}{|c|}{ Factors controlled or adjusted for } \\
\hline & & $\begin{array}{l}\text { Appropriate: age, severity of illness, severity of } \\
\text { dementia, and payment status adjustments }\end{array}$ & $\begin{array}{l}\text { Inappropriate: quality measures used in other studies; } \\
\text { measures of intensity of care }\end{array}$ \\
\hline Castle $2001^{\text {w59 }}$ & $\begin{array}{l}\text { United States; } 1992-7 \text { and 1999; OSCAR (1992-7); } 13 \\
162 \text { nursing homes }\end{array}$ & ADLs; private pay occupancy & Nurse staffing \\
\hline $\begin{array}{l}\text { Dubois et al } \\
2001^{\text {w60 }}\end{array}$ & $\begin{array}{l}\text { Eastern townships of Quebec (Canada); 1996; resident } \\
\text { interviews; } 88 \text { nursing homes }\end{array}$ & Age & $\begin{array}{l}\text { Staff to resident ratio; percentages of professionals } \\
\text { among staff }\end{array}$ \\
\hline Keith $2001^{\text {w61 }}$ & $\begin{array}{l}\text { A "Midwestern state"; } 2 \text { year period (year not specified); } \\
\text { primary mail questionnaire and Area Agencies on Aging; } \\
\text { questionnaire data from } 633 \text { volunteers and } 1886 \\
\text { records }\end{array}$ & $\begin{array}{l}\text { Adjusted analysis but none of } 4 \text { selected appropriate } \\
\text { factors included }\end{array}$ & None \\
\hline $\begin{array}{l}\text { O'Neill et al } \\
2001^{\text {w62 }}\end{array}$ & United States; 1999; OSCAR; 1098 homes & ADLs; dementia & $\begin{array}{l}\text { Staffing (administration, medical director, RNs and LPNs, } \\
\text { nurse aides per } 10 \text { residents) }\end{array}$ \\
\hline Castle $2002^{\text {w63 }}$ & United States; 1996-9; OSCAR; 14042 homes & ADLs; payment status & Psychiatric problems \\
\hline Lee et al $2002^{\text {w64 }}$ & $\begin{array}{l}\text { Taiwan; 1999; Quality Assessment Index; } 28 \text { homes (12 } \\
\text { chain/FP, } 12 \text { independent/FP, and } 4 \text { NFP) }\end{array}$ & $\begin{array}{l}\text { Adjusted analysis but none of } 4 \text { selected appropriate } \\
\text { factors included }\end{array}$ & Ratio of nurses to average number of daily residents \\
\hline Allen et al $2003^{\text {w66 }}$ & $\begin{array}{l}\text { Connecticut; 1998-2000; Long-Term Care Ombudsman } \\
\text { Program complaint data; } 3360 \text { complaints from } 261 \\
\text { nursing homes }\end{array}$ & Medicaid occupancy & $\begin{array}{l}\text { Staffing (full time employee ratio of RNs, LPNs, and } \\
\text { certified nursing assistants to total number of beds/ } \\
\text { facility) }\end{array}$ \\
\hline $\begin{array}{l}\text { Anderson et al } \\
2003^{\text {w67 }}\end{array}$ & $\begin{array}{l}\text { Texas; date of survey administration not provided } \\
\text { (secondary data from 1995); survey data from nursing } \\
\text { home staff and } 1995 \text { Texas MDS; } 164 \text { nursing homes }\end{array}$ & $\begin{array}{l}\text { Adjusted analysis but none of } 4 \text { selected appropriate } \\
\text { factors included }\end{array}$ & None \\
\hline $\begin{array}{l}\text { Castle and } \\
\text { Banaszak-Holl } \\
2003^{\text {w68 }}\end{array}$ & United States; 1999; OSCAR; 15834 homes & Dementia; severity of illness (ADLs) & None \\
\hline $\begin{array}{l}\text { Harrington and } \\
\text { Swan } 2003^{\text {w69 }}\end{array}$ & California; 1999; state cost reports; 1155 homes & Payment status & None \\
\hline $\begin{array}{l}\text { Weech- } \\
\text { Maldonado et al } \\
2003^{\text {w70 }}\end{array}$ & $\begin{array}{l}\text { NY, KS, VT, ME, and SD; 1996; Health Care Financing } \\
\text { Administration Investment Analyst Nursing Home } \\
\text { Database (MDS+, OSCAR) }\end{array}$ & $\begin{array}{l}\text { Adjusted analysis but none of } 4 \text { selected appropriate } \\
\text { factors included }\end{array}$ & None \\
\hline Lau et al $2004^{\text {w72 }}$ & United States; 1996; MEPS NHC, 3372 residents & Age; Medicaid coverage; mental status; ADL limitations & $\begin{array}{l}\text { RN to non-RN ratio; } R N \text { to resident ratio; influenza } \\
\text { vaccination percentage }\end{array}$ \\
\hline $\begin{array}{l}\text { Castle and } \\
\text { Engberg } 2005^{\text {w73 }}\end{array}$ & $\begin{array}{l}\mathrm{MO}, \mathrm{TX}, \mathrm{CT} \text {, and NJ; 2003; primary data on staff turnover } \\
\text { from mailed survey, OSCAR for remaining information; } \\
526 \text { homes }\end{array}$ & $\begin{array}{l}\text { Illness severity (ADLs, incontinent bladder/bowel); } \\
\text { dementia }\end{array}$ & $\begin{array}{l}\text { Staffing (full time equivalent RNs, LPNs, nursing } \\
\text { assistants/100 beds) }\end{array}$ \\
\hline $\begin{array}{l}\text { Chesteen et al } \\
2005^{\mathrm{w} 74}\end{array}$ & $\begin{array}{l}\text { Utah; 1999; survey of certified nursing assistants, Utah } \\
\text { Medicare/Medicaid certification program, and } \\
\text { operational data reported to the state of Utah; } 890 \\
\text { certified nursing assistants at } 42 \text { nursing homes }\end{array}$ & $\%$ Medicaid & None \\
\hline $\begin{array}{l}\text { Gruber-Baldini et } \\
\text { al } 2005^{\text {w75 }}\end{array}$ & $\begin{array}{l}4 \text { US states; year of data acquisition unclear; survey of } \\
\text { resident care supervisors; } 347 \text { residents with dementia } \\
\text { in } 10 \text { homes and } 35 \text { residential care/assisted living } \\
\text { facilities }\end{array}$ & Cognitive status & $\begin{array}{l}\% \text { of supervisory staff trained; } \% \text { of direct care providers } \\
\text { trained }\end{array}$ \\
\hline $\begin{array}{l}\text { Intrator et al } \\
2005^{\mathrm{w} 76}\end{array}$ & $\begin{array}{l}\text { United States (minus Alaska, District of Columbia, } \\
\text { Hawaii, and Puerto Rico); } 1993 \text { to 2002; OSCAR and } \\
\text { recent survey done by authors; } 137190 \text { surveys from } 17 \\
635 \text { distinct nursing facilities }\end{array}$ & $\begin{array}{l}\text { Residents not paid for by Medicare or Medicaid (\%), } \\
\text { Medicare residents (\%) }\end{array}$ & Total nurse hours per patient day> 4.55 \\
\hline $\begin{array}{l}\text { McGregor et al } \\
2005^{\text {w77 }}\end{array}$ & $\begin{array}{l}\text { British Columbia; 2001; British Columbia Labour } \\
\text { Relations Board; } 167 \text { homes }\end{array}$ & Severity of illness (levels of care) & None \\
\hline $\begin{array}{l}\text { Starkey et al } \\
2005^{\text {w78 }}\end{array}$ & NY, ME, VT, and SD; 1996; MDS+, OSCAR; 1121 homes & Payment status & None \\
\hline $\begin{array}{l}\text { Stevenson } \\
2005^{\text {w79 }}\end{array}$ & $\begin{array}{l}\text { Massachusetts; 1998-2002; nursing home complaints } \\
\text { received by Massachusetts DPH, OSCAR, and MDS QI; } \\
539 \text { nursing homes }\end{array}$ & ADLs & $\begin{array}{l}\text { Survey deficiencies; staffing (nurse, aide); indwelling } \\
\text { catheter; pressure sores }\end{array}$ \\
\hline White $2005^{\text {w80 }}$ & $\begin{array}{l}\text { United States; 1997, 2001; OSCAR; 10 } 000 \text { homes in } \\
\text { each year (unclear from article) }\end{array}$ & Payment status & None \\
\hline $\begin{array}{l}\text { Williams et al } \\
2005^{\text {w81 }}\end{array}$ & $\begin{array}{l}4 \text { US states; year of data acquisition unclear; primary } \\
\text { survey of resident care supervisors; } 331 \text { residents with } \\
\text { dementia in } 10 \text { homes and } 35 \text { residential care/assisted } \\
\text { living facilities }\end{array}$ & Cognitive status & Staffing \\
\hline $\begin{array}{l}\text { McGregor et al } \\
2006^{\text {w82 }}\end{array}$ & $\begin{array}{l}\text { British Columbia; } 1 \text { April-1 August 1999; British } \\
\text { Columbia Linked Health Database; } 43065 \text { residents }\end{array}$ & None for crude analysis & None for crude analysis \\
\hline
\end{tabular}

$A D L s=a c t i v i t i e s$ of daily living; DON=director of nursing; FP=for profit; IADLs=instrumental activities of daily living; $L P N=l i c e n s e d$ practical nurse; $L V N=$ licensed vocational nurse; MMMS=modified mini-mental state examination; NFP=not for profit; RN=registered nurse; SMAF=functional autonomy measurement system.

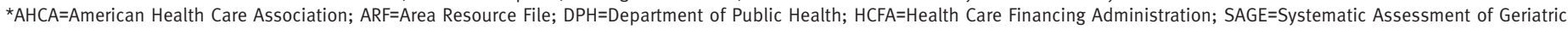
Drug Use via Epidemiology; see table 3 for others. 
Table 6|Quality of care measures and outcomes of studies comparing for-profit and not-for-profit nursing homes (public and private NFP homes): favoured directions represent those with higher quality care

\begin{tabular}{ll}
$\begin{array}{l}\text { Study } \\
\text { Winn, } 1974^{\text {w35 }}\end{array}$ & $\begin{array}{l}\text { Quality measure } \\
\text { Staffing-No of equivalent hours per patient day (1 RN hour=1 h; other employees' } \\
\text { hours in proportion to } 1 \text { as their salary is to that of an RN), aide/orderly hours per } \\
\text { patient day, LPN hours per patient day } \\
\text { RN hours per patient day, total nursing care hours per patient day }\end{array}$ \\
\hline $\begin{array}{ll}\text { Riporttella-Mullerand } \\
\text { Slesinger 1982 }\end{array}$ & $\begin{array}{l}\text { Complaints to Wisconsin Nursing Homes Ombudsman Program; deficiencies in } \\
\text { Wisconsin Office of Quality Compliance survey }\end{array}$ \\
\hline Nyman 1984 & $\begin{array}{l}\text { No of Medicaid violations weighted by severity in 1979, and composite variable for } \\
\text { Wisconsin's Quality Assurance Project; each quality measure examined with } 2 \\
\text { models }\end{array}$
\end{tabular}
models

\begin{tabular}{ll}
\hline Brunetti et al $1990^{\text {w38 }}$ Cardiopulmonary resuscitation policy prevalence and quality of policy compared with \\
10 model criteria
\end{tabular}

Munroe $1990^{\text {w39 }}$ Deficiencies at California state licensing "276 health deficiencies," assessed for licensing (state) and certification (Medicare and Medicaid); staffing (turnover)

Cherry $1991^{\text {w40 }} \quad$ Aggregate measure of staffing hours, pressure ulcer prevalence, urethral catheterisation, urinary tract infections/resident, and antibiotic use (poorly explained)

Kanda and Mezey Staffing: RN staffing-No of full time RNs/100 beds, No of part time RNs/100 beds, $1991^{\mathrm{w} 41} \quad$ total No of nursing staff/100 beds, proportion of part time and full time RNs to total nursing staff

Cherry $1993^{\text {w42 }} \quad$ Poor nursing care (composed of four items) and non-compliance (defined as infraction in any of eight federally established categories of inspection)

Zinn et al $1993^{\text {w43 }}$ Mortality - deaths per 100 residents; prevalence of pressure ulcers, restraint use, and urethral catheterisation

Zinn $1993^{\text {w44 }} \quad$ Staffing (RNs per resident, LPNs per resident, NAs per resident); catheter use rate; restraint use rate; tube fed rate; \% not toileted

Graber and Sloane Restraint use prevalence at 1991 North Carolina Annual Survey

$1995^{\text {w45 }}$

Christensen and Surveys of health and safety deficiencies and life safety code deficiencies

Beaver $1996^{\text {w46 }}$

Mukamel $1997^{\text {w47 }}$ Deterioration of decubitus ulcers; physical restraint use prevalence; dehydration rates; deterioration in ADLs

Anderson et al $1998^{\text {w48 }}$

Average resident outcomes concerning verbal/physical aggression; other disruptive behaviour; geriatric-chair, wrist-mitten or vest-belt restraints; contracture; pressure ulcer; dehydration; urinary tract infection; fracture within preceding 3 months; and percentage improvements in resident outcomes between two time points

Bliesmer et al Change in total dependence score (TDS) based on sum of eight ADLs: dressing, $1998^{\text {w49 }} \quad$ grooming, bathing, eating, bed mobility, transferring, walking and toileting

\section{Castle and Fogel Restraint use prevalence}

$1998^{\text {w50 }}$

Anderson and

Lawhorne $1999^{\text {w5 }}$

Advance care directive prevalence; feeding tube prevalence; drug errors noted on survey; pressure ulcer prevalence; restraint use prevalence; staffing—direct care hours per resident per day; urinary catheterisation prevalence

\section{Bravo et al 1999w52 QUALCARE scale*}

Castle $1999^{\text {w53 }} \quad$ Psychoactive drug use prevalence

Ballou 2000w54 Deficiencies (federal violations—definition unclear); staffing—RNs + LPNs per bed, total nursing staff per bed

Castle $2000^{\text {w55 }} \quad$ Restraint use (changes with legislation)

Castle $2000^{\text {w5 }}$

Castle $2001^{\text {w57 }}$

Restraint use citations

Deficiencies in OSCAR† for 19 quality of care items; prevalence of pressure ulcers, psychoactive drug use, restraint use, and urethral catheterisation

Castle $2001^{\text {w58 }} \quad$ Deficiency citations in OSCAR, subdivided into provision of appropriate services, training provisions and resident assessments

Castle $2001^{\text {w59 }} \quad$ Early adoptors of innovation (as measured through 13 special care units or subacute Non-significantly favoured FP services)

\section{Outcome}

Non-significantly favoured NFP for all comparisons

All significant $(P<0.05)$ comparisons favoured NFP: favoured NFP ( $\mathrm{P}<0.001)$ for complaints; not significant (direction unclear) for deficiencies

All significant $(\mathrm{P}<0.05)$ comparisons favoured FP: for violations, one model significantly favoured FP ( $<0.05)$ and the other non-significantly favoured FP; for the composite variable, non-significantly favoured FP and NFP in two different models

Mixed results: presence of policy, non-significantly favoured FP; quality of policy, difference not noted

All significant $(\mathrm{P}<0.05)$ comparisons favoured NFP: non-significantly favoured FP for deficiencies; favoured NFP for staffing ( $P<0.001)$

Non-significantly favoured NFP (only one aggregate outcome reported)

All significant $(P<0.05)$ comparisons favoured NFP: favoured NFP for part time RNs/100 beds ( $P<0.001$ ), total nursing staff/100 beds ( $P<0.001)$; nonsignificantly favoured NFP for full time RNs/100 beds, proportion of full time and part time RNs to total nursing staff

All significant ( $\mathrm{P}<0.05$ ) comparisons favoured NFP; FP showed non-significantly more poor care and significantly greater non-compliance ( $P<0.01)$

Non-significantly favoured NFP for all measures

Mixed results: FP significantly associated with fewer RNs per resident, more LPNs per resident, higher catheter use rate, higher restraint use rate, and higher \% not toileted; FP non-significantly associated with more NAs per resident and higher tube fed rate

Non-significantly favoured NFP

Significantly favoured NFP ( $\mathrm{P}<0.005)$, meaning FP had more deficiencies

Mixed results: FP associated with worse outcomes for deterioration in decubitus ulcers $(P=0.004)$ and physical restraints $(P=0.0001)$ and better outcomes for dehydration rates $(\mathrm{P}=0.0001)$; no significant difference for accident rates and No of deficiencies

Not significant (direction not noted)

Mixed results: when deaths and discharges were excluded from the TDS scores, ownership status was no longer significant; FP status was significantly associated with higher chances of discharge in 2 of the 3 years examined (1990 (Pr0.001) and 1991 (P<0.01)); NFP status was significantly associated with higher chances of death in 2 of the 3 years examined (1990 and 1991, P<0.001 for both)

Significantly favoured FP (P<0.001)

All significant ( $\mathrm{P}<0.05)$ comparisons favoured NFP: non-significantly favoured NFP for drug errors, non-significantly favoured FP for restraint use prevalence; favoured NFP for all other comparisons

Not significant (direction not noted)

Non-significantly favoured FP

Favoured NFP (unclear if significant)

Mixed results: favoured NFP ( $<<0.001)$ for not increasing restraint use with legislation; favoured FP ( $\mathrm{P}$ 0.05) for decreasing restraint use with legislation Favoured NFP ( $\mathrm{P}<0.05)$

All significant ( $\mathrm{P}<0.05)$ comparisons favoured NFP; favoured NFP for deficiencies, psychoactive drug use, restraint use prevalence; not significant (direction unclear) for deficiencies, urethral catheterisation

Favoured NFP ( $<<0.001)$

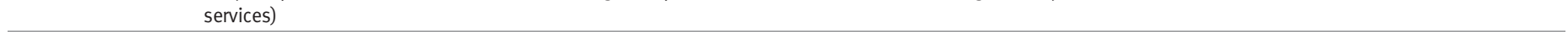




\begin{tabular}{|c|c|c|}
\hline Study & Quality measure & Outcome \\
\hline Dubois et al $2001^{\mathrm{w} 60}$ & QUALCARE scale* & Not significant (direction not noted) \\
\hline Keith $2001^{\text {w61 }}$ & Ombudsman program complaints & Favoured NFP $(P=0.001)$ \\
\hline O'Neill et al $2001^{\text {w62 }}$ & $\begin{array}{l}\text { Deficiencies in OSCAR† (total deficiencies and severe deficiencies rated F and higher, } \\
\text { where maximum No of deficiencies was } 85 \text { to reduce outlier effects); staffing- } \\
\text { average total nursing hours per resident day }\end{array}$ & Favoured NFP (P<0.01) for all comparisons \\
\hline Castle $2002^{\text {w63 }}$ & Restraint use prevalence & $\begin{array}{l}\text { Favoured FP: } 1 \text { citation ( } P<0.05) ; 2 \text { consecutive yearly citations ( } \mathrm{P}<0.01) ; 3 \\
\text { consecutive yearly citations ( } \mathrm{P}<0.01)\end{array}$ \\
\hline Lee et al $2002^{\text {w64 }}$ & QAl & Significantly favoured NFP for $3 / 5$ categories and for total QAI score (P<0.05) \\
\hline Allen et al $2003^{\text {w65 }}$ & Ombudsman program complaints & $\begin{array}{l}\text { Mixed results: non-significantly favoured NFP for both care complaints } \\
(P=0.79) \text { and abuse complaints }(P=0.20)\end{array}$ \\
\hline Allen et al $2003^{\text {w66 }}$ & Ombudsman complaints & Significantly favoured NFP $(P=0.021)$ \\
\hline $\begin{array}{l}\text { Anderson et al } \\
2003^{\text {w67 }}\end{array}$ & $\begin{array}{l}\text { Residents' behaviour (verbal or physical aggressiveness or other disruptive } \\
\text { behaviour); restraint use; complication of immobility; or sustaining a fracture in } \\
\text { previous } 3 \text { months }\end{array}$ & $\begin{array}{l}\text { Mixed results: non-significantly favoured FP for resident behaviours and higher } \\
\text { restraint use; non-significantly favoured NFP for complications of immobility } \\
\text { and fractures }\end{array}$ \\
\hline $\begin{array}{l}\text { Harrington and Swan } \\
2003^{\text {w69 }}\end{array}$ & Staffing_total nurse and RN hours per resident day & Favoured NFP (P<0.01) \\
\hline $\begin{array}{l}\text { Weech-Maldonado et } \\
\text { al } 2003^{\text {w70 }}\end{array}$ & $\begin{array}{l}\text { Outcome quality (cognitive decline, mood decline, pressure ulcer prevalence); } \\
\text { process quality (restraint use prevalence, urinary catheterisation prevalence); } \\
\text { staffing (ratio of RN hours to total nursing hours) }\end{array}$ & $\begin{array}{l}\text { Mixed results: non-significantly favoured FP for outcome quality; nearly } \\
\text { significantly favoured NFP ( }<0.10) \text { for process quality; non-significantly } \\
\text { favoured NFP for staffing }\end{array}$ \\
\hline $\begin{array}{l}\text { Baumgarten et al } \\
2004^{\text {w71 }}\end{array}$ & Pressure ulcer incidence & Favoured NFP \\
\hline Lau et al $2004^{\text {w72 }}$ & Inappropriate medical prescriptions by Beer's criteria & Non-significantly favoured NFP \\
\hline $\begin{array}{l}\text { Castle and Engberg } \\
2005^{\text {w73 }}\end{array}$ & $\begin{array}{l}\text { Contracture prevalence; deficiencies in OSCAR†-focused on quality deficiencies } \\
\text { (19/185 assessed); restraint use prevalence; pressure ulcer prevalence; } \\
\text { psychoactive drug use prevalence (\% of residents given anti-anxiety, sedative/ } \\
\text { hypnotic, and antipsychotic drugs); quality index-normalised measure of other } \\
\text { indices (physical restraint prevalence, urethral catheterisation prevalence, } \\
\text { contracture prevalence, pressure ulcer prevalence, psychoactive drugs use, and } \\
\text { deficiency data) }\end{array}$ & $\begin{array}{l}\text { All significant }(P<0.05) \text { comparisons favoured NFP: non-significantly favoured } \\
\text { NFP for all comparisons except for restraint prevalence, which favoured NFP } \\
(P<0.01)\end{array}$ \\
\hline $\begin{array}{l}\text { Gruber-Baldini et al } \\
2005^{\text {w75 }}\end{array}$ & $\begin{array}{l}\text { Depression (of resident) prevalence, measured by modified Cornell scale for } \\
\text { depression in dementia }\end{array}$ & Significantly favoured NFP (odds ratio $2.53 \mathrm{FP} / \mathrm{NFP}, 95 \% \mathrm{Cl} 1.29$ to 4.98 ) \\
\hline Intrator et al $2005^{\mathrm{w} 76}$ & Employment of nurse practitioners or physician assistants on staff & Non-significantly favoured FP \\
\hline $\begin{array}{l}\text { McGregor et al } \\
2005^{\text {w77 }}\end{array}$ & $\begin{array}{l}\text { Staffing: mean (dietary, housekeeping and laundry staff) hours per resident day; } \\
\text { mean (RN, LPN and NA) hours per resident day; mean activity aide hours per resident } \\
\text { day; mean dietary staff hours per resident day; mean housekeeping staff hours per } \\
\text { resident day; mean laundry staff hours per resident day; mean LPN hours per resident } \\
\text { day; mean NA hours per resident day; mean RN hours per resident day (each measure } \\
\text { assessed in intermediate care, intermediate/extended care, and multilevel nursing } \\
\text { home care settings) }\end{array}$ & $\begin{array}{l}\text { All significant (P<0.05) comparisons favoured NFP_favoured NFP for all } \\
\text { comparisons except: non-significantly favoured NFP for intermediate/ } \\
\text { extended care mean activity aide hours per resident day, multilevel care mean } \\
\text { dietary staff hours per resident day, multilevel care mean laundry staff hours } \\
\text { per resident day, intermediate care or intermediate/extended care mean LPN } \\
\text { hours per resident day, mean NA hours per resident day in all three care } \\
\text { settings, mean RN hours per resident day in intermediate and multilevel care } \\
\text { settings; no direction to relation for multilevel care mean LPN hours per } \\
\text { resident day; non-significantly favoured FP for mean laundry staff hours per } \\
\text { resident day in all three care settings }\end{array}$ \\
\hline Starkey et al $2005^{w 78}$ & $\begin{array}{l}\text { Cognitive decline between OSCAR assessments; mood decline between OSCAR } \\
\text { assessments; prevalence of pressure ulcers, restraint use, and urinary } \\
\text { catheterisation }\end{array}$ & $\begin{array}{l}\text { All significant (P<0.05) comparisons favoured NFP: non-significantly favoured } \\
\text { NFP for all measures except restraint use prevalence, which non-significantly } \\
\text { favoured FP, and urethral catheterisation prevalence, which significantly } \\
\text { favoured NFP }\end{array}$ \\
\hline Stevenson $2005^{\text {w79 }}$ & Ombudsman office complaints & Significantly favoured NFP $(P<0.05)$ \\
\hline White $2005^{\text {w80 }}$ & $\begin{array}{l}\text { Deficiencies in OSCAR†; pressure ulcer incidence (OSCAR); restraint use incidence } \\
(\text { OSCAR) } \ddagger\end{array}$ & $\begin{array}{l}\text { All significant }(\mathrm{P}<0.05) \text { comparisons favoured NFP: significantly favoured NFP } \\
(\mathrm{P}<0.05) \text { in all measures except pressure ulcer incidence, which non- } \\
\text { significantly favoured FP }\end{array}$ \\
\hline $\begin{array}{l}\text { Williams et al } \\
2005^{\text {w81 }}\end{array}$ & Resident self reported pain using Philadelphia Geriatric Centre pain intensity scale & Significantly favoured NFP (odds ratio $2.99 \mathrm{FP} / \mathrm{NFP}, 95 \% \mathrm{Cl} 1.40$ to 6.39 ) \\
\hline $\begin{array}{l}\text { McGregor et al } \\
2006^{\text {w82 }}\end{array}$ & $\begin{array}{l}\text { Hospital admission rate for anaemia, dehydration, falls, pneumonia, urinary tract } \\
\text { infection, and pressure ulcers/gangrene; mortality }\end{array}$ & $\begin{array}{l}\text { All significant ( } \mathrm{P}<0.05) \text { comparisons favoured NFP: favoured NFP for all } \\
\text { measures except falls, urinary tract infection, and pressure ulcer admissions } \\
\text { (non-significantly favoured NFP) and mortality (no direction) }\end{array}$ \\
\hline \multicolumn{3}{|c|}{ 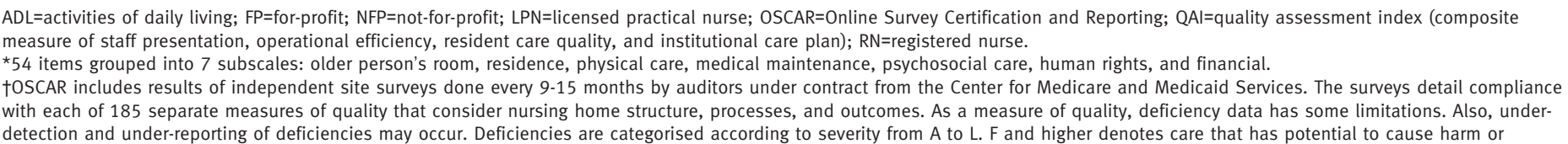 } \\
\hline
\end{tabular}

detection and under-reporting of deficiencies may occur. Deficiencies are categorised according to severity from A to L. F and higher denotes care that has potential to cause harm or

immediate jeopardy to patients. In some years, deficiencies assessed varied from state to state.

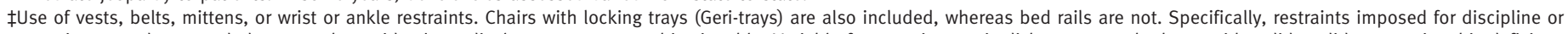

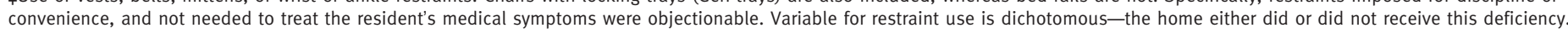
Restraint use was verified by surveyors during the day for OSCAR. 


\begin{tabular}{|c|c|c|c|c|c|}
\hline \multirow[b]{2}{*}{ Outcome } & \multirow[b]{2}{*}{ Summary study characteristics } & \multicolumn{4}{|c|}{ Interaction $\mathrm{P}$ value } \\
\hline & & FP-NFP v FP-private NFP & $\begin{array}{l}\text { Above median } v \text { below } \\
\text { median appropriate } \\
\text { adjustment score }\end{array}$ & $\begin{array}{l}\text { Presence } v \text { absence of } \\
\text { inappropriate adjustment, } \\
\text { among studies with } \\
\text { adjusted analysis }\end{array}$ & $\begin{array}{l}\text { Data collection before or } \\
\text { during } 1987 v \text { after } 1987\end{array}$ \\
\hline $\begin{array}{l}\text { More extensively } \\
\text { trained staff or more } \\
\text { staff }\end{array}$ & $\begin{array}{l}13 \text { studies had poolable data, from } 1971 \text { - } \\
2002 ; 3 \text { removed for data overlap; } 10 \text { meta- } \\
\text { analysed—4 collected data after } 1987,1 \\
\text { used primary data, } 1 \text { had data from Canada } \\
\text { (remainder from United States) }\end{array}$ & $\begin{array}{l}0.64 \text { for FP-private NFP; ratio of } \\
\text { effect sizes } 1.09(95 \% \mathrm{Cl} 1.07 \\
\left.\text { to } 1.12, \mathrm{P}<0.001, \mathrm{I}^{2}=0 \%\right)\end{array}$ & 0.15 & 0.99 & 0.66 \\
\hline $\begin{array}{l}\text { Lower pressure } \\
\text { ulcer prevalence }\end{array}$ & $\begin{array}{l}16 \text { studies had poolable data, from } 1987 \text { - } \\
2003 ; 5 \text { removed for data overlap; } 11 \text { meta- } \\
\text { analysed-2 used primary data, } 1 \text { had data } \\
\text { from Canada (remainder from United States) }\end{array}$ & $\begin{array}{l}0.76 \text { for FP-private NFP } \\
\text { comparison; ratio of effect } \\
\text { sizes } 0.89(0.82 \text { to } 0.98 \\
\left.P=0.02, I^{2}=39.3 \%\right)\end{array}$ & 0.42 & 0.54 & $\begin{array}{l}\text { All meta-analysed data } \\
\text { collected after } 1987\end{array}$ \\
\hline $\begin{array}{l}\text { Lower physical } \\
\text { restraint prevalence }\end{array}$ & $\begin{array}{l}13 \text { studies had poolable data from } 1987 \text { - } \\
2003 ; 5 \text { removed for data overlap; } 8 \text { meta- } \\
\text { analysed-1 used primary data }\end{array}$ & $\begin{array}{l}0.84 \text { for FP-private NFP } \\
\text { comparison; ratio of effect } \\
\text { sizes } 0.94(0.78 \text { to } 1.14 \text {, } \\
\left.P=0.53,\left.\right|^{2}=84.9 \%\right)\end{array}$ & 0.86 & 0.13 & $\begin{array}{l}\text { All meta-analysed data } \\
\text { collected after } 1987\end{array}$ \\
\hline $\begin{array}{l}\text { Fewer deficiencies } \\
\text { on government } \\
\text { surveys }\end{array}$ & $\begin{array}{l}13 \text { studies had poolable data from } 1976- \\
2003 ; 6 \text { removed for data overlap; } 7 \text { meta- } \\
\text { analysed-2 collected data before } 1987\end{array}$ & $\begin{array}{l}0.56 \text { for FP-private NFP } \\
\text { comparison; ratio of effect } \\
\text { sizes } 0.92(0.79 \text { to } 1.06 \\
\left.P=0.25, I^{2}=63.1 \%\right)\end{array}$ & 0.80 & 0.54 & $\begin{array}{l}0.11 \text {; for data collected after } \\
1987, \text { pooled effect size } 0.73 \\
(95 \% \text { Cl } 0.54 \text { to } 0.97, P=0.03 \\
\left.I^{2}=67.9 \%\right) \text { favouring NFP } \\
\text { homes; for data collected } \\
\text { before or during } 1987 \text {, poolec } \\
\text { effect size } 1.09 \text { ( } 0.94 \text { to } 1.25 \\
\left.P=0.25, I^{2}=0 \%\right)\end{array}$ \\
\hline
\end{tabular}

$F P=$ for-profit; NFP=not-for-profit.

outcomes of those studies that compared for-profit and privately owned not-for-profit facilities. Similarly, tables 5 and 6 present the detailed study characteristics and outcomes of studies that compared for-profit and not-for-profit (publicly and privately owned) facilities.

We meta-analysed data for the four most commonly used quality measures. Table 7 presents a summary of the characteristics of studies meta-analysed, along with the results of sensitivity analyses to explain heterogeneity among studies in each meta-analysis. Two meta-analyses showed statistically significant results favouring higher quality care in not-for-profit nursing homes.

We found more or higher quality staffing in not-forprofit homes (ratio of effect 1.11, 95\% confidence

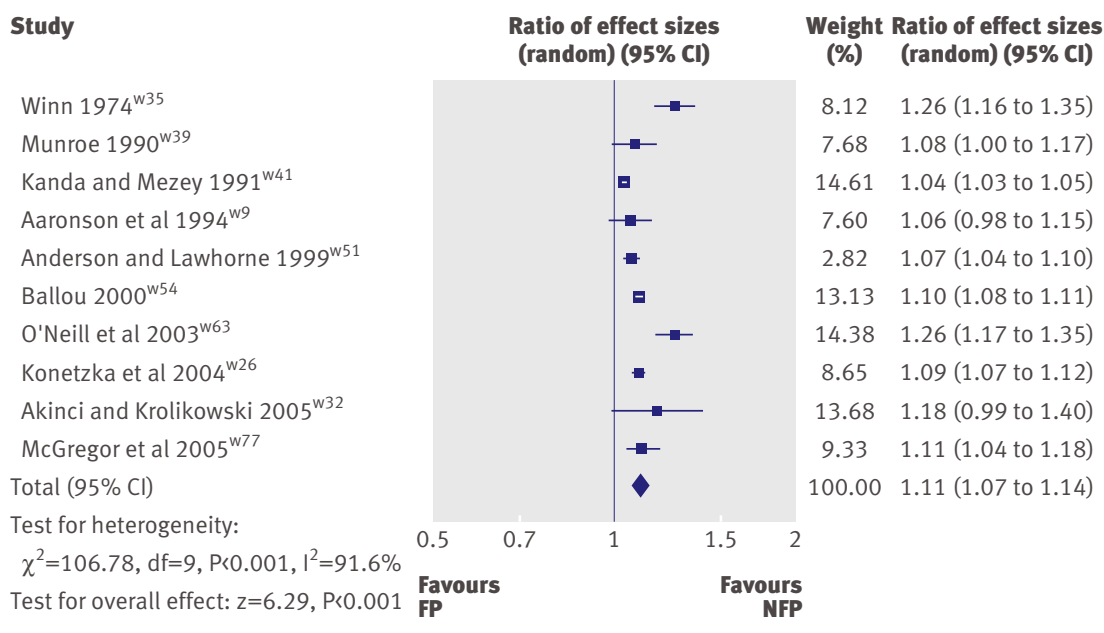

Fig 2 Ratio of effect sizes for staffing quality in for-profit (FP) and not-for-profit (NFP) nursing homes. Ratios listed represent effect size in NFP homes compared with that in FP homes. Ratio $>1$ indicates that NFP homes had more, or higher quality, staffing (that is, favours NFP) interval 1.07 to $1.14, \mathrm{P}<0.001, \mathrm{I}^{2}=91.6 \%$ ) (fig 2 ). We found a similar result favouring not-for-profit homes when assessing staffing hours alone, with a ratio of effect of 1.11 (1.08 to $1.14, \mathrm{P}<0.001, \mathrm{I}^{2}=70.3 \%$ ), an absolute hours increase of 0.42 (0.31 to 0.53$)$ hours/ resident/bed/day, and a relative hours increase of $11 \%(8 \%$ to $14 \%)$. When the only non-US study was excluded, we arrived at a similar ratio of effect for more or higher quality staffing in not-for-profit homes of 1.11 (1.07 to $1.15, \mathrm{P}<0.001, \mathrm{I}^{2}=92.4 \%$ ).

We found a lower prevalence of pressure ulcers in not-for-profit homes (odds ratio 0.91, 95\% confidence interval 0.83 to $0.98, \mathrm{P}=0.02, \mathrm{I}^{2}=52.1 \%$ ), with an absolute risk reduction of $0.59 \%(0.13 \%$ to $1.12 \%)$ and a relative risk reduction of $8.4 \%(1.9 \%$ to $16 \%)$ (fig 3$)$. When the only non-US study was excluded, we arrived at a similar odds ratio favouring lower pressure ulcer prevalence in not-for-profit homes of 0.89 (0.82 to $\left.0.97, \mathrm{P}=0.007, \mathrm{I}^{2}=50.2 \%\right)$.

The remaining two meta-analyses showed nonstatistically significant differences. We found less use of physical restraints in not-for-profit homes (odds ratio $0.93,0.82$ to $1.05, \mathrm{P}=0.25, \mathrm{I}^{2}=74.6 \%$ ) (fig 4 ) and fewer deficiencies in governmental regulatory assessments in not-for-profit homes (ratio of effect 0.90, 0.78 to $1.04, \mathrm{P}=0.17, \mathrm{I}^{2}=59.8$ ) (fig 5).

Funnel plots for the four meta-analyses did not suggest publication bias. A priori hypotheses did not explain the observed heterogeneity (table 7 ).

\section{DISCUSSION}

Our systematic review identified 82 studies comparing quality of care in for-profit and not-for-profit nursing homes. More studies had all statistically significant analyses showing higher quality in not-for-profit 


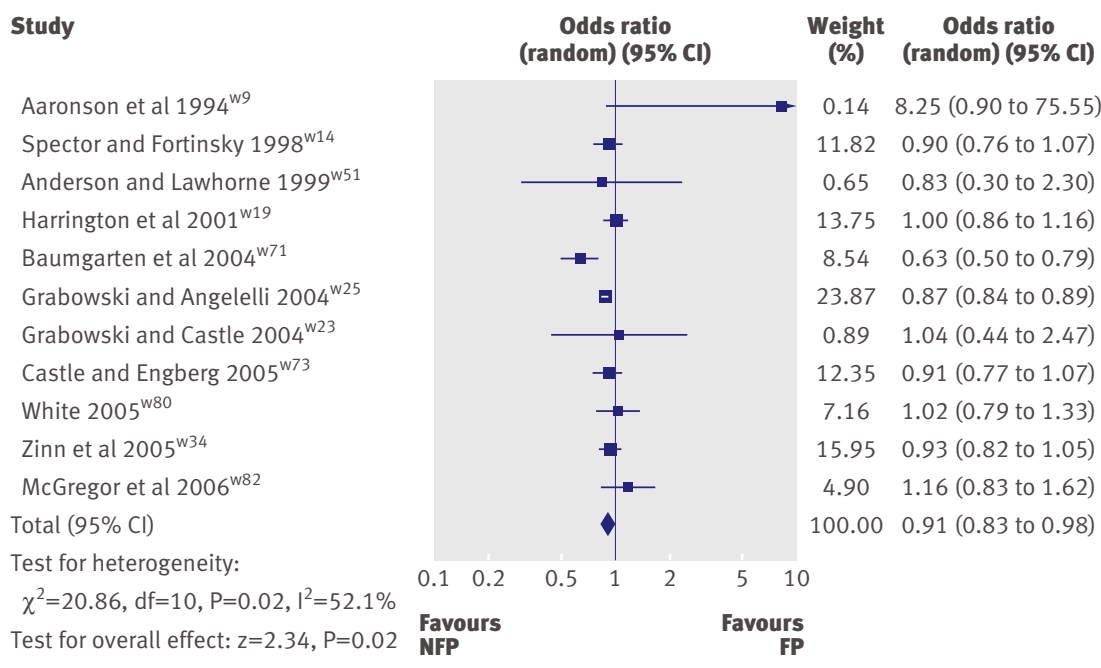

Fig 3 | Odds ratios (OR) comparing pressure ulcer prevalence in for-profit (FP) and not-for-profit (NFP) nursing homes. OR $<1$ indicates lower risk of pressure ulcers in NFP facilities than in FP facilities, suggesting that NFP facilities deliver higher quality care

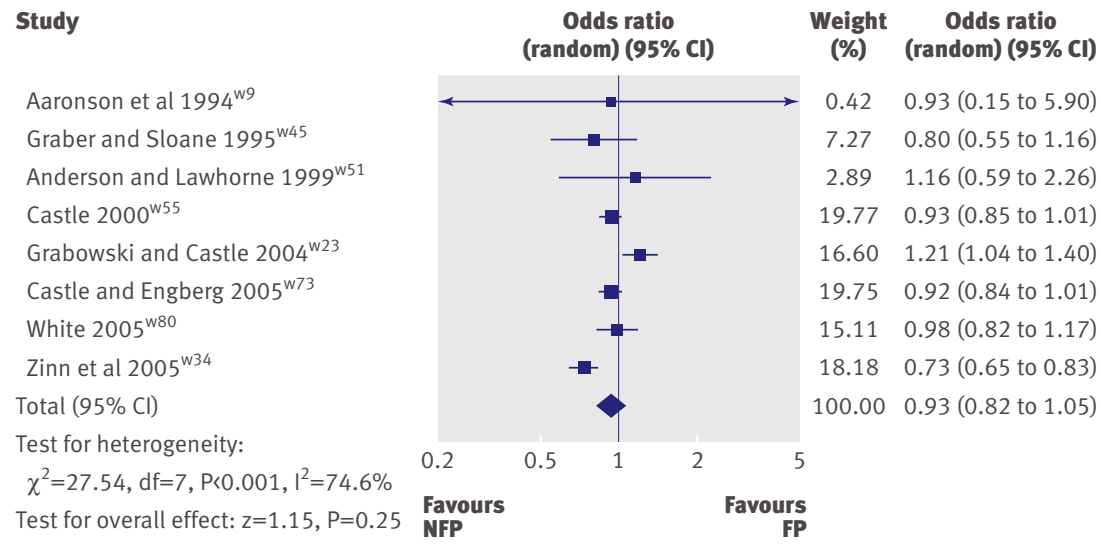

Fig 4 | Odds ratios (OR) comparing physical restraint prevalence in for-profit (FP) and not-forprofit (NFP) nursing homes. OR $<1$ represents less physical restraint use in NFP facilities than FP facilities, suggesting that NFP facilities deliver higher quality care

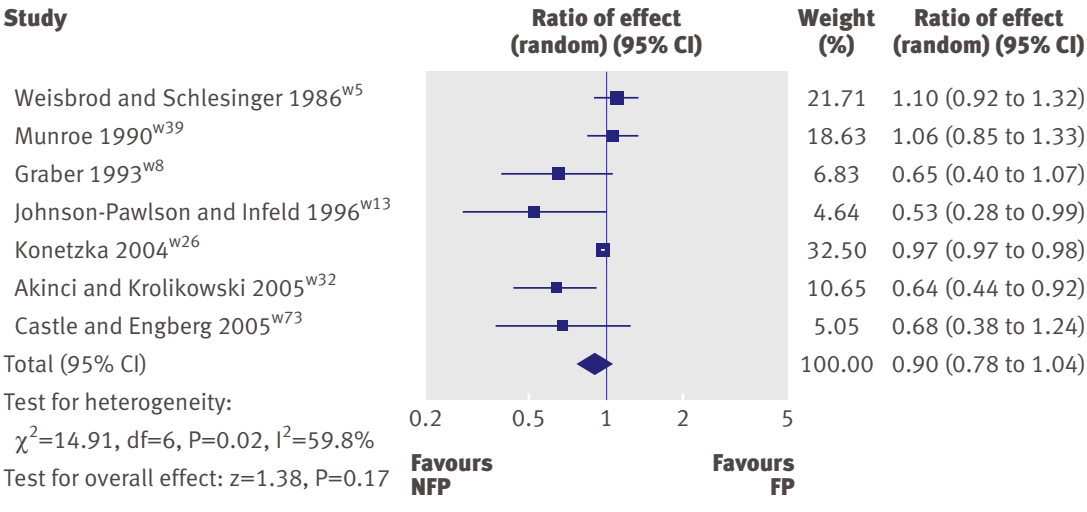

Fig 5 Ratio of effect sizes for regulatory deficiencies in for-profit (FP) and not-for-profit (NFP) nursing homes. Ratios listed represent effect size in NFP facilities compared with that in FP facilities. Ratio $<1$ represents fewer deficiencies in NFP homes, suggesting that NFP homes deliver higher quality care nursing homes than in for-profit nursing homes. Many studies, however, showed no significant differences in quality by ownership, and a small number showed statistically significant differences in favour of for-profit homes. This pattern held true when we compared for-profit homes with both privately owned and publicly owned not-for-profit facilities. Pooled analyses of the four most commonly used quality measures showed statistically significant results favouring higher quality care in not-for-profit homes for staffing and prevalence of pressure ulcers and non-statistically significant differences favouring not-for-profit homes in physical restraint use and regulatory agency deficiencies. The large observed heterogeneity was not explained by our a priori hypotheses.

\section{Previous systematic reviews}

Two previous systematic reviews have compared quality of care in for-profit and not-for-profit nursing homes. In 1991 Davis and colleagues found that many studies showed that higher quality of care was provided in not-for-profit nursing homes; however, weaknesses in the methodological design of the included studies limited the conclusions that could be drawn. ${ }^{30}$ In 2002 Hillmer and colleagues did a systematic review comparing for-profit and not-for-profit facilities (including publicly owned facilities), focusing on studies in North America completed after the previous review. ${ }^{31}$ This study also concluded that notfor-profit facilities provided better quality care than for-profit facilities.

\section{Strengths and weaknesses of this review}

We did a comprehensive search, which identified 60 studies not included in previous reviews. We assessed studies spanning four decades and published in any language. We masked study results before determining eligibility and did duplicate citation screening, data abstraction, and quality assessment. We contacted authors for missing data and received responses from most of them. We compared quality of care in both forprofit versus not-for-profit nursing homes and forprofit versus privately owned not-for-profit nursing homes, did pooled analyses of quality of care measures, and found largely consistent results.

Our review has limitations resulting from the characteristics of the studies included. No randomised trials have compared quality of care across nursing home ownership, and no such trials are ever likely to be done. Furthermore, most studies are from the United States, which raises questions of generalisability to other jurisdictions.

Studies are also limited in that no standard definition of quality of care exists. The result is that studies used a very wide variety of alternative measures of quality. Even when the same measures were used, standardised approaches to the application of those measures were lacking. For example, meta-analysis for number and qualifications of staff fails to take into account staff turnover, the use of agency staff, and the professional mix of staff. ${ }^{25}$ 


\section{WHAT IS ALREADY KNOWN ON THIS TOPIC}

The quality and appropriateness of care delivered in nursing homes is a major concern for the public, policy makers, and media

Controversy exists about whether for-profit compared with not-for-profit ownership affects quality of care

\section{WHAT THIS STUDY ADDS}

Most studies suggest a trend towards higher quality care in not-for-profit facilities than in for-profit homes, but a large proportion of studies show no significant trend

Moreover, several eligible studies used administrative databases, which further limits the comprehensiveness and quality of the data. For example, the American Online Survey Certification and Reporting (OSCAR) database comprises self reported data from nursing home administrators; surveyors verify only a sample. Careful duplicate abstraction of data from patients' charts with a priori definitions or, ideally, direct assessment of care provision would be preferable.

Our meta-analyses are limited in that many authors could not remove publicly owned facilities from their datasets for our for-profit versus privately owned notfor profit analysis. However, in our sensitivity analyses, results comparing for-profit and not-for-profit facilities were not significantly different from those in which we restricted the not-for-profit facilities to those for which we could confirm ownership.

\section{Heterogeneity}

On the one hand, one might see our results as compellingly favouring not-for-profit facilities. The gradient between studies in which all significant measures favoured not-for-profit (40 studies) and those in which all measures favoured for-profit (3) is large (table 1). All four meta-analyses favoured not-for-profit institutions, and two reached statistical significance.

On the other hand, 37 studies had mixed results (some measures favoured for-profit, some not-forprofit) and considerable heterogeneity was present in the results of the meta-analyses. This suggests that although the average effect is clear, that effect probably varies substantially across situations. The variability is probably explained, in part, by a variety of factors that vary within categories of for-profit and not-for-profit homes, including management styles, motivations, and organisational behaviour. For example, for-profit facilities owned and operated by investor owned corporations may have different motivations than facilities owned by small private businesses or single proprietors. Not-for-profit facilities run by charities might differ in structure and process from those run by municipalities; not-for-profit facilities that are managed by for-profit nursing home companies may function differently from those that are not.

We have partially mitigated this problem with our a priori hypotheses (extent of appropriate adjustments, year of data collection, geography and political environment, primary compared with secondary data collection, and, in particular, public versus private ownership of not-for-profit facilities). None of these variables, however, explained the substantial heterogeneity of our results. The studies failed to specify characteristics of individual nursing homes in sufficient detail to allow analyses exploring factors such as those listed above (ownership by corporation, small business, charitable organisation of municipality; management of not-for-profit homes by for-profit providers).

\section{Significance of this study}

Most of the studies in our systematic review showed lower quality of care in for-profit nursing homes than in not-for-profit nursing homes. However, a large proportion of studies showed no significant difference in quality of care by ownership. In the long term care market, in which funding is often provided by the government at fixed rates, both for-profit and not-forprofit facilities face an economic challenge that may affect staffing and other determinants of quality of care. In the for-profit context, however, shareholders expect $10-15 \%$ returns on their investments, ${ }^{32}$ taxes may account for 5-6\% of expenses, and facilities tend to have higher executive salaries and bonuses, so forprofit facilities have a strong incentive to minimise expenditures. ${ }^{33}$ Minimising expenditures may lead to lower quality staffing and higher rates of adverse events (such as pressure ulcers), which may be reflected in citations for deficiency.

Proving causality by using observational studies is difficult. Furthermore, given their variability, the results do not imply a blanket judgment of all institutions. Some for-profit institutions may provide excellent quality care, whereas some not-for-profit institutions may provide inferior quality of care.

Our findings are, however, consistent with findings of higher risk adjusted death rates in for-profit hospitals and dialysis facilities as shown in previous reviews, ${ }^{18} 19$ as well as providing insight into average effects. Given the absolute risk reduction in pressure ulcers of $0.59 \%$, we can estimate that pressure ulcers in 600 of 7000 residents with pressure ulcers in Canada and 7000 of 80000 residents with pressure ulcers in the United States are attributable to for-profit ownership. Similarly, given an absolute increase in nursing hours of 0.42 hours per resident per bed per day, we can estimate that residents in Canada would receive roughly 42000 more hours of nursing care a day and those in the United States would receive 500000 more hours of nursing care a day if not-for-profit institutions provided all nursing home care. These estimates are based on the 2006 census from Canada showing that 100740 of 252561 nursing home residents resided in for-profit nursing homes and the 2000 census from the United States showing a total of 1720500 nursing home residents. ${ }^{3435}$ These estimates assume that two thirds of US nursing home residents live in for-profit facilities. 


\section{Further research and conclusions}

Although this review has fully assessed the data available comparing for-profit and not-for-profit nursing home care, additional work is needed to compare the costs between these types of facilities and to evaluate the consistency of these findings outside of the United States and Canada. Although we have extensively evaluated the literature comparing quality of care in for-profit, charitable organisation owned, and government owned nursing homes, the available studies did not allow comparison of the possible impact of factors such as subcategory of for-profit ownership (for example, chain $v$ non-chain, investor $v$ small business ownership, municipality $v$ federal government ownership). Nursing home management companies further complicate the relation between ownership and quality of care. These are all important areas that warrant further research.

We acknowledge the outstanding work of Deborah Maddock, Denise Healey, Shelley Anderson, Michelle Murray, Monica Owen, and Laurel Grainger who coordinated this study. We thank our foreign article reviewers Janek Brozek, Matthias Briel, Toshi Furukawa, Marjuka Makela, Ben de Mol, Paola Muti, Patricia Smith, Kristian Thorlund, and David Wei. We appreciate the work of Dana Keilty, Navneet Binepal, Tony Soeyonggo, and Minji Kim, who blinded articles for us. We thank Christina Lacchetti, Michael Levy, and Rajesh Hiralal, who reviewed articles for us, and Diane Heels-Ansdell for her statistical help. We also thank the authors of included studies who did additional analyses for our systematic review: Chappin White, Robert Weech-Maldonado, and Ann L. Gruber-Baldini. Contributors: VRC, PJD, GHG, and TS conceived and designed the study OB, MB, NB, VRC, DJC, PJD, GHG, SB, JWB, KEB, TH, JNL, BP, NCR, HS, BS, $\mathrm{SBS}, \mathrm{QZ}$, and KW were involved in data acquisition. VRC, GHG, QZ, and PJD analysed and interpreted the data. VRC drafted the manuscript. GHG PJD, and QZ critically revised the manuscript for important intellectual content. QZ and SDW provided statistical expertise. VRC, PJD, and GHG are the guarantors.

Funding: Atkinson Foundation Grant; the study sponsor did not contribute to the study design. JWB is funded by a Canadian Institutes of Health research fellowship award. DJC, MB, and JNL are supported, in part, by their respective Canada Research chairs. PJD is supported by a Canadian Institutes of Health Research new investigator award. HS is funded by a European Commission: The Human Factor, Mobility and Marie Curie Actions scientist reintegration grant (IGR 42192).

Competing interests: None declared.

Ethical approval: Not needed.

1 European Commission. Long-term care in the European Union. 2008 http://ec.europa.eu/employment_social/spsi/docs/ social_protection $/ 2008 / \mathrm{hc}$ _ttc_en.pdf.

2 Georgiades S. Quality nursing home care in Cyprus: are elder residents content with their treatment? J Gerontol Soc Work 2008;50(3-4):3-24.

3 Konetzka RT, Stearns SC, Park J. The staffing-outcomes relationship in nursing homes. Health Serv Res 2008;43:1025-42.

4 Mukamel DB, Glance LG, Li Y, Weimer DL, Spector WD, Zinn JS, et al. Does risk adjustment of the CMS quality measures for nursing homes matter? Med Care 2008;46:532-41.

5 Castle NG, Liu D, Engberg J. The association of Nursing Home Compare quality measures with competition and occupancy rates. Healthc Qual 2008;30(2):4-14.

6 BBC News. Nursing home residents 'in pain'. 2007. http://news.bbc co.uk/2/hi/health/6471485.stm

7 Welsh M, Benzie R. No minimum standard for nursing care. 2008. www.thestar.com/News/Ontario/article/445152.

8 The Toronto Star. Troubling report on nursing homes. 2008. www. thestar.com/article/453994.

9 Covello L. Nursing home quality: more hype than hazard? 2008. www.foxbusiness.com/portal/site/fb/ menuitem.5b2f8f9bb693bd972f08aa8738d48a0c/? vgnextoid=ac387b770dbba110VgnVCM10000086c1a8c0RCRD\& re directed=true.
10 Duhigg C. At many homes, more profit and less nursing. 2007. www. nytimes.com/2007/09/23/business/23nursing.html?

$r=1$ \&pagewanted=all\&oref=slogin\#.

11 CBC News. Another seniors home in B.C. not up to standard, NDP says. 2007. www.cbc.ca/canada/british-columbia/story/2007/10/ 04/bc-senior.html.

12 US Department of Health and Human Services. Nursing home compare. www.medicare.gov/NHCompare.

13 Kerrison SH, Pollock AM. Care for older people in the private sector in England. BM/ 2001:323:566-9.

14 Tyszko P, Wierzba WM, Kanecki K, Ziolkowska A. Transformation of the ownership structure in Polish healthcare and its effects. CentEur / Med 2007;2:528-38

15 Statistics Canada. Residential care facilities 2003/2004. Ottawa, ON: Statistics Canada, 2006 (available at http://www.statcan.gc.ca/ pub/83-237-x/83-237-x2006001-eng.pdf).

16 Shapiro E, Tate RB. Monitoring the outcomes of quality of care in nursing homes using administrative data. Can J Aging 1995;14:755-68.

17 Devereaux PJ, Choi PT, Lacchetti C, Weaver B, Schünemann HJ, Haines T, et al. A systematic review and meta-analysis of studies comparing mortality rates of private for-profit and private not-forprofit hospitals. CMA/ 2002;166:1399-406.

18 Devereaux PJ, Schunemann HJ, Ravindran N, Bhandari M, Garg AX, Choi PT, et al. Comparison of mortality between private for-profit and private not-for-profit hemodialysis centres: a systematic review and meta-analysis. JAMA 2002;288:2449-57.

19 Devereaux PJ, Heels-Ansdell D, Lacchetti C. Payments for care at private for-profit and private not-for-profit hospitals. CMAJ 2004; $170: 1817-24$

20 American Medical Association. Quality of Care Council on Medical Service. JAMA 1986;256:1032-4

21 Donabedian A. The quality of care: how can it be assessed? JAMA 1988;260:1743-8

22 Mukamel DB. Risk-adjusted outcome measures and quality of care in nursing homes. Medical Care 1997;35(4):367-85.

23 Institute of Medicine. Improving the quality of care in nursing homes. Washington, DC: National Academy Press, 1986.

24 Abt Associates. Appropriateness of minimum nurse staffing ratios in nursing homes: report to Congress. (Phase II final, volume 1.) Baltimore, MD: Centres for Medicare and Medicaid Services, 2001 (available from www.allhealth.org/BriefingMaterials/AbtNurseStaffingRatios(12-01)-999.pdf).

25 Castle NG, Engberg J. The influence of staffing characteristics on quality of care in nursing homes. Health Serv Res 2007;42:1822-47.

26 Hutt E, Radcliffe TA, Liebrecht D, Fish R, McNulty M, Kramer AM. Associations among nurse and certified nursing assistant hours per resident per day and adherence to guidelines for treating nursing home acquired-pneumonia. J Gerontol A Biol Sci Med Sci 2008;63:1105-11.

27 Goodson J, Jang W, Rantz M. Nursing home care quality: insights from a bayesian network approach. Gerontologist 2008;48:338-48

28 National Cancer Institute. Dictionary of cancer terms. http:// cancernet.nci.nih.gov/Templates/db_alpha.aspx?CdrID=441254

29 Identifying and measuring heterogeneity. In: Higgins JPT, Green S, eds. Cochrane handbook for systematic reviews of interventions Version 5.0.0 [updated February 2008]. The Cochrane Collaboration, 2008 (available at www.mrc-bsu.cam.ac.uk/cochrane/handbook/ chapter_9/9_5_2_identifying_and_measuring_heterogeneity.htm).

30 Davis MA. On nursing home quality: a review and analysis. Med Care Rev 1991;48:129-68.

31 Hillmer MP, Wodchis WP, Gill SS, Anderson GM, Rochon PA. Nursing home profit status and quality of care: is there any evidence of an association? Med Care Res Rev 2005;62:139-66.

32 Nudelman PM, Andrews LM. The "values added" of not-for-profit health plans. N Engl J Med 1996;334:1057-9.

33 Friedman BS, Hattis PA, Bogue RJ. Tax exemption and community benefits of not for-profit hospitals. Adv Health Econ Health Serv Res 1990;11:131-58.

34 Statistics Canada. Residential care facilities 2006/2007. Ottawa, ON: Statistics Canada,

2008 (available at www.statcan.ca/english/freepub/83-237-XIE/ 83-237-XIE2009001.pdf).

35 United States Census Bureau. Census 2000 PHC-T-26. Population in group quarters by type, sex and age, for the United States: 1990 and 2000. 2003. www.census.gov/population/www/cen2000/briefs/ phc-t26/tables/tab01.pdf.

Accepted: 21 April 2009 